\title{
Airborne and ground-based measurements of the trace gases and particles emitted by prescribed fires in the United States
}

\author{
I. R. Burling ${ }^{1}$, R. J. Yokelson ${ }^{1}$, S. K. Akagi ${ }^{1}$, S. P. Urbanski ${ }^{2}$, C. E. Wold ${ }^{2}$, D. W. T. Griffith ${ }^{3}$, T. J. Johnson ${ }^{4}$, \\ J. Reardon ${ }^{2}$, and D. R. Weise ${ }^{5}$ \\ ${ }^{1}$ University of Montana, Department of Chemistry, Missoula, MT 59812, USA \\ ${ }^{2}$ USDA Forest Service, Rocky Mountain Research Station, Fire Sciences Laboratory, Missoula, MT 59808, USA \\ ${ }^{3}$ University of Wollongong, Department of Chemistry, Wollongong, New South Wales, Australia \\ ${ }^{4}$ Pacific Northwest National Laboratories, Richland WA 99354, USA \\ ${ }^{5}$ USDA Forest Service, Pacific Southwest Research Station, Riverside, CA, USA
}

Received: 8 June 2011 - Published in Atmos. Chem. Phys. Discuss.: 30 June 2011

Revised: 17 November 2011 - Accepted: 28 November 2011 - Published: 7 December 2011

\begin{abstract}
We have measured emission factors for 19 trace gas species and particulate matter $\left(\mathrm{PM}_{2.5}\right)$ from 14 prescribed fires in chaparral and oak savanna in the southwestern US, as well as conifer forest understory in the southeastern US and Sierra Nevada mountains of California. These are likely the most extensive emission factor field measurements for temperate biomass burning to date and the only published emission factors for temperate oak savanna fuels. This study helps to close the gap in emissions data available for temperate zone fires relative to tropical biomass burning. We present the first field measurements of the biomass burning emissions of glycolaldehyde, a possible precursor for aqueous phase secondary organic aerosol formation. We also measured the emissions of phenol, another aqueous phase secondary organic aerosol precursor. Our data confirm previous observations that urban deposition can impact the $\mathrm{NO}_{\mathrm{x}}$ emission factors and thus subsequent plume chemistry. For two fires, we measured both the emissions in the convective smoke plume from our airborne platform and the unlofted residual smoldering combustion emissions with our groundbased platform. The smoke from residual smoldering combustion was characterized by emission factors for hydrocarbon and oxygenated organic species that were up to ten times higher than in the lofted plume, including high 1,3-butadiene and isoprene concentrations which were not observed in the lofted plume. This should be considered in modeling the air
\end{abstract}

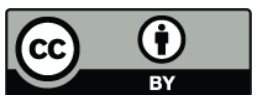

Correspondence to: R. J. Yokelson (bob.yokelson@umontana.edu) quality impacts for smoke that disperses at ground level. We also show that the often ignored unlofted emissions can significantly impact estimates of total emissions. Preliminary evidence suggests large emissions of monoterpenes in the residual smoldering smoke. These data should lead to an improved capacity to model the impacts of biomass burning in similar temperate ecosystems.

\section{Introduction}

Biomass burning is the largest source of primary, fine carbonaceous particles and a significant source of trace gases in the global atmosphere (Bond et al., 2004; Crutzen and Andreae, 1990) and impacts both the chemical composition as well as the radiative balance of the atmosphere. The majority of biomass burning occurs unregulated in the tropics (Crutzen and Andreae, 1990). In the United States, formal land management programs use prescribed burning to reduce wildfire hazards, improve wildlife habitats, and increase access (Biswell, 1989; Wade and Lunsford, 1989). Many fire-adapted ecosystems depend on the regular occurrence of fire for survival (Keeley et al., 2009). In these ecosystems, land managers may implement relatively frequent prescribed burning (every 1-4 yr) of small amounts of biomass under conditions with favorable atmospheric dispersion. The temperate regions of the southeastern and southwestern US experience both wildfires and prescribed burning; however, the relative proportion of prescribed burns differs between the two regions. Even though the annual average area burned

Published by Copernicus Publications on behalf of the European Geosciences Union. 
by wildfire in the southeastern US was 479000 ha for 2001 to 2010 , another approximately 650000 ha were burned by prescribed fires. (NIFC, 2011). Wildfire activity was similar in the southwestern US (New Mexico, Arizona, and southern California) where on average 364,000 ha burned annually over 2001 to 2010 (NIFC, 2011). However, prescribed fire has been employed much less in the southwest. The National Interagency Fire Center reported a 10-yr average (2001-2010) of 77,000 ha (NIFC, 2011) in the southwest, only about $1 / 10$ of the annual prescribed burning in the southeastern US.

In the US, burned area data are needed to estimate biomass burning emissions for air quality forecasting and to guide the development of land and air shed management policy. To this end, fire detection (Giglio et al., 2003) and burn scar (Giglio et al., 2009; Roy et al., 2008; Urbanski et al., 2009a) observations from the MODIS (Moderate Resolution Imaging Spectroradiometer) satellite have seen increasing use to map burned area. While under optimum conditions MODIS can detect fires as small as $100 \mathrm{~m}^{2}$ (Giglio et al., 2003), in practice, due to various factors (e.g. fire behavior, cloud cover) the detection rate may be less than $20 \%$ for fires $<100$ ha in size (Urbanski et al., 2009a). The low MODIS detection rate for small fires is not critical in the western US where large wildfires dominate annual burned area; however, it poses a significant impediment to the development of fire emission inventories in the southeast where small, prescribed fires (average size $=60 \mathrm{ha}$ ) comprise $\sim 60 \%$ of annual burned area for 2001-2010 (NIFC, 2011).

The contribution of these US temperate burning emissions is relatively small on the global scale (van der Werf et al., 2010). However, such burns have the potential to impact local visibility and local and regional air quality and emissions data from these regions are therefore necessary for land managers to devise appropriate prescribed burning strategies. Comprehensive field measurements of emissions from biomass burning in these regions are relatively scarce. For field measurements of biomass burning emissions an airborne measurement platform is usually required for sampling flaming combustion emissions due to the lofting of smoke from convection created by high flame temperatures. In an airborne study, Yokelson et al. (1999) measured ten of the most common trace gas emissions from a wildfire and two prescribed fires in North Carolina. In other airborne field studies, Cofer et al. (1988), Hegg et al. (1988) and Radke et al. (1991) measured the emissions of a limited number of chemical species from burning of chaparral that was impacted by deposition of nitrogenous compounds from adjacent urban areas. Hardy et al. (1996) measured smoke emissions from chaparral fires in southern California using instrumentation suspended from a cable directly over the fires. They reported emission factors (EF) for particulate matter (PM), $\mathrm{CO}, \mathrm{CO}_{2}, \mathrm{CH}_{4}$, and total non-methane hydrocarbons (NMHC) by combustion process (i.e. flaming, smoldering).
Prolonged smoldering after local convection from the flame front has ceased is often termed "residual smoldering combustion" (RSC, Bertschi et al., 2003) and is responsible for many of the negative air quality impacts of prescribed burning on a local scale (e.g. smoke exposure complaints, visibility-limited highway accidents (Achtemeier, 2006)). Ground-based systems are usually required for measurements of RSC smoke emissions. The emissions from RSC burning are quite different from those of flaming combustion due to the lower combustion efficiency. The strategies adopted by land managers for prescribed burning typically minimize the amount of RSC and its impacts on local populations. In contrast, wildfires normally burn when "fire danger" is at high levels and forest floor moisture is at a minimum (Deeming et al., 1978), often resulting in significant amounts of RSC. There are usually few or no options for reducing smoke impacts on populated areas from wildfires. Although not a factor in this study, in some wildfires, organic soils (peat) may also burn contributing to RSC. Residual smoldering combustion can continue for weeks after initial ignition and can account for a large portion of the total biomass consumed in a fire (Bertschi et al., 2003; Rein et al. 2009). Naeher et al. (2006) measured $\mathrm{PM}_{2.5}$ and $\mathrm{CO}$ from prescribed fires from sites in South Carolina with large amounts of down, dead fuel to investigate the effects of preburn mechanical mastication. We are unaware of any other peer-reviewed field measurements of the emissions from RSC in the temperate regions of the US.

Laboratory measurements of the emissions from biomass burning have some advantages over field studies, including the application of more extensive instrumentation, higher smoke concentrations leading to potentially more measurable species, and the ability to sample all the smoke for an entire fire. Also, fuel characteristics and elemental composition are easier to determine in the laboratory. Due to these advantages, laboratory measurements are complementary to field measurements but emissions data from field measurements are usually considered more representative of real fires (Christian et al., 2003) since they reflect actual environmental conditions, real fuels, and similar scale fire behavior. In fact, this work is part of a larger study of the emissions of biomass burning of fuel types from biomes of the southeastern and southwestern US that has included already published laboratory studies (Burling et al., 2010; Hosseini et al., 2010; Roberts et al., 2010; Veres et al., 2010; Warneke et al., 2011). Here we present smoke emissions data from field measurements conducted during prescribed fires burning similar fuels to those collected for the laboratory phase. We also include smoke measurements of the lofted emissions from aircraft measurements and the RSC emissions using ground-based instruments that were conducted on the same fire. Such comprehensive, simultaneous measurements are rare and especially informative. A more detailed comparison between the laboratory and field measurements, including all instrumentation, will be discussed in a future synthesis paper. 
Table 1. Fire name, location, date, fuels, and size for fires sampled in this study.

\begin{tabular}{|c|c|c|c|c|c|c|c|}
\hline Fire Name & Location & Date & Fuel Description & $\begin{array}{l}\text { Area } \\
\text { Burned } \\
\text { (ha) }\end{array}$ & $\begin{array}{l}\text { Latitude } \\
\text { (degrees) }\end{array}$ & $\begin{array}{l}\text { Longitude } \\
\text { (degrees) }\end{array}$ & $\begin{array}{l}\text { MODIS } \\
\text { hotspot? }\end{array}$ \\
\hline Camp Lejeune IA plot & Camp Lejeune, NC & 11 Feb 2010 & Conifer forest understory & 36 & 34.5798 & -77.3167 & $\mathrm{no}^{\mathrm{a}}$ \\
\hline Little Florida 2 & Wilmington, $\mathrm{NC}$ & 12 Feb 2010 & Conifer forest understory & 24 & 34.0687 & -78.2817 & no ${ }^{b}$ \\
\hline Bear Pen & Wilmington, $\mathrm{NC}$ & $15 \mathrm{Feb} 2010$ & Conifer forest understory/grass airstrip & & 34.1287 & -78.3388 & no ${ }^{b}$ \\
\hline Camp Lejeune ME plot & Camp Lejeune, NC & 1 Mar 2010 & $\begin{array}{l}\text { Masticated, resprouted shrubs/untreated } \\
\text { conifer forest understory }\end{array}$ & 677 & 34.6422 & -77.4617 & yes \\
\hline Turtle & Fresno, $\mathrm{CA}$ & 10 Nov 2009 & Sierra mixed conifer with shrub understory & 1050 & 36.9670 & -119.0803 & yes $^{\mathrm{c}}$ \\
\hline Shaver & Fresno, CA & 10 Nov 2009 & Conifer forest understory & 30 & 37.0652 & -119.2897 & $\mathrm{no}^{\mathrm{c}}$ \\
\hline Test fire Grant A & Vandenberg AFB, CA & 5 Nov 2009 & Coastal sage scrub/grass & 7 & 34.7915 & -120.5253 & no ${ }^{\mathrm{b}}$ \\
\hline Grant block A & Vandenberg AFB, CA & 11 Nov 2009 & Coastal sage scrub/grass & 110 & 34.7925 & -120.5297 & no ${ }^{b}$ \\
\hline Grant block B & Vandenberg AFB, CA & 11 Nov 2009 & Maritime chaparral/grass & 100 & 34.7983 & -120.5250 & no ${ }^{b}$ \\
\hline Williams fire & Buellton, CA & 17 Nov 2009 & Coastal Maritime chaparral & 81 & 34.7003 & -120.2083 & yes \\
\hline
\end{tabular}

${ }^{a}$ Fire was ignited after the daytime Terra and Aqua overpasses. ${ }^{b}$ Fire was obscured by clouds during the daytime Terra and Aqua overpasses. ${ }^{\mathrm{c}}$ Fire was obscured by clouds during the daytime Terra and Aqua overpasses; however, the Turtle Fire was detected by the nighttime Terra overpass.

\section{Experimental details}

All fires in this study were sampled from the air using a US Forest Service Twin Otter aircraft outfitted for atmospheric chemistry research as described in Sects. 2.2-2.3. Some of the fires were also sampled from the ground using equipment described in Sect. 2.4. We sampled a total of 14 prescribed fires and key parameters (e.g. location, fuel types, area burned) are summarized for each fire in Table 1.

\subsection{Site descriptions}

The three Grant burns of 5 Nov and 11 Nov 2009 were located on Vandenberg Air Force Base (VAFB) in California (CA). The vegetation burned consisted of coastal sage scrub (black sage (Salvia mellifera), California goldenbush (Ericameria ericoides), and California sagebrush (Artemisia californica)) intermixed with large areas of grass in unit block A. Block B was essentially maritime chaparral composed of ceanothus (Ceanothus impressus, Ceanothus cuneatus), black sage, chamise (Adenostoma fasciculatum), manzanita (Arctostaphylos rudis, Arctostaphylos purissima) and coast live oak (Quercus agrifolia), with much less grass. A test fire was performed on a small isolated section of block A on 5 November. Due to high dead fuel moisture this fire did not carry well and was suspended after 7 ha burned. Subsequent fair weather dried the fuels and the remaining 110 ha burned readily on the morning of 11 Nov. Block B $(\sim 100$ ha $)$ was then burned during the afternoon of 11 Nov. The small ( $\sim 10$ ha) Atmore burn on the morning of $18 \mathrm{Nov}$ was carried out as a training exercise for the Ventura County Fire Department in unsheltered coastal sage scrub fuels. The $17 \mathrm{Nov}$
Williams prescribed fire was located on a hillside near Buellton, $\mathrm{CA}$ and burned 81 ha of coastal California sage scrub chaparral, intermixed with coyote brush (Baccharis pilularis), button black sage (Salvia mellifera), and coast live oak (Quercus agrifolia). More details on the Williams fire fuels and meteorology are given elsewhere (Akagi et al., 2011a). Due mostly to air-space restrictions, the Williams fire was also the only fire out of the 14 for which the post-emission plume evolution could be measured. The results of those extensive measurements are also reported separately by Akagi et al. (2011a). In all, five fires in fuels loosely classified as "chaparral" were sampled. Another important biotic community in semi-arid areas of the southwestern US is Madrean oak woodland (Brown 1982). We sampled one large prescribed fire in an oak savanna (the T2 burn, $\sim 356$ ha) at the perimeter of Fort Huachuca, Arizona (AZ) on 29 March 2010. The site was on an east-facing slope in the foothills of the Huachuca Range and had an open canopy dominated by Emory oak (Quercus emoryii) with a few alligator-bark junipers (Juniperus deppeana) and grass (Eragrostis lehmannii). Most of the fuel consumption was in the grass component of the fuel complex. Based on mean visual estimates the grass fuel consumption was $87 \%$.

We also report the emissions from eight prescribed understory fires in coniferous forests. In all cases, only the understory burned in these fires. We sampled the Turtle and Shaver prescribed fires on 10 Nov 2009 located in a midmontane forest in the Sierra National Forest of California east of Fresno. The Turtle prescribed burn was conducted in the mixed conifer phase dominated by sugar pine (Pinus lambertiana) and ponderosa pine (Pinus ponderosa) with California black oak (Quercus kelloggii), California 
incense cedar (Calocedrus decurrens), and white fir (Abies concolor) and a shrub understory of deerbrush (Ceanothus integerrimus), buckbrush (Ceanothus cuneatus), and probably greenleaf manzanita (Arctostaphylos patula). This fire was ignited using the DAID (Delayed Aerial Ignition Device) system which drops plastic balls containing potassium permanganate injected with ethylene glycol from a helicopter. The Shaver prescribed burn overstory was dominated by ponderosa pine and California incense cedar with scattered sugar pine and black oak. The understory was dominated by dense thickets of whiteleaf manzanita (Arctostaphylos viscid), bearclover (Chamaebatia foliolosa), with white fir and California incense cedar regeneration. Due to mountain pine beetle activity and previous lack of fire, accumulated dead and downed woody fuels exceeded $28 \mathrm{~kg} \mathrm{~m}^{-2}$. We also sampled the smoke from six prescribed fires in pine-dominated forests in the coastal lowlands of North Carolina (NC) during February and March of 2010. The 11 February fire at Camp Lejeune (IA plot) had a moderate density coniferous overstory of loblolly pine (Pinus taeda) and burned understory fuels, which consisted mainly of fetterbush shrubs ( $L y$ onia lucida), with some herbaceous fuels. This unit had been burned $\sim 2-3$ yr prior and had light fuel loadings. In addition, due to high fuel moisture, helicopter ignition using the DAID system was required. The second Camp Lejeune (hereafter referred to as "CL") fire was on 1 March 2010 (ME plot) and burned through a sequence of several fuel types beginning with (1) an area of recently masticated fuels, resprouted fetterbush shrubs and understory hardwoods including red maple (Acer rubrum) and sweetgum (Liquidambar styraci$f l u a$ ), followed by (2) an untreated moderate density understory (red bay (Persea borbonia), red maple, gallberry (Ilex glabra), and fetterbush) with a moderate density loblolly pine overstory, and finally, (3) an area of 1-2 yr. regrowth of small shrubs of fetterbush and swamp titi (Cyrilla racemiflora) with grasses. The two prescribed fires on 12 February (Little Florida Burns 1 and 2) were conducted by the Nature Conservancy. The first unit had been logged and contained mostly wiregrass (Aristida stricta) in the interior with a longleaf pine (Pinus palustris) and pond pine (Pinus serotina) coniferous perimeter with a gallberry understory. Some of the fuels and soil were saturated with water. The second fire was adjacent to the first and consumed the moderate density gallberry understory of a longleaf and pond pine forest. The Bear Pen fire on 15 February was conducted to maintain a grass airstrip and also reduce surrounding loblolly pine forest understory vegetation. Due to strong winds, the smoke from this burn stayed close to the ground and only a limited number of samples of low concentration could be obtained. The Holly Shelter prescribed fire was carried out on 5 March 2010. The unit occupied a "sand ridge" and some adjacent low-lying areas. The overstory was dominated by loblolly pine. An aircraft maintenance issue limited us to acquiring four low concentration smoke samples early in the fire. Thus, pine litter was the primary fuel burned during our aircraft sampling and shrub consumption was limited during the airborne sampling of this fire.

Ground-based sampling of the smoke from RSC using our mobile ground-based instrument (Sect. 2.4) was possible on two of the NC fires described above: the ME fire at Camp Lejeune (1 March) and the Holly Shelter fire (5 March). The fuels consumed by RSC in these two fires were quite different, allowing us to sample a range of RSC emissions. At the ME fire the RSC samples reflected consumption of large diameter stumps, dead and downed wood, and a live scarred tree. The RSC samples at Holly Shelter were smoke generated mostly by burning pine litter and some small shrubs.

Given the reliance on MODIS for fire detection and burned area mapping, we report on the sensor's detection of the prescribed fires in this study (Table 1). Five of the 14 fires registered MODIS fire detections. Of the nine fires that were not detected by MODIS, seven were ignited and burned under cloud cover that likely obscured observation and another was ignited after the last daytime satellite overpass. The collection 5 MODIS burned area product (MCD45, Roy et al., 2008) did not register any of the fires in our study. Overall, this is likely attributable to the fact that many of the fires were understory burns or were of a size comparable to the nominal resolution of the MODIS burned area product ( 25 ha pixel). The large (1050 ha) Turtle Fire was apparently not detected due to snowfall following the burn. The MODIS burned area product flagged the area encompassing the Turtle Fire as obscured by snow or high aerosol and in fact, the Assistant Fire Management Officer involved with the Turtle burn reported that the area received about $2.5 \mathrm{~cm}$ of accumulated snow the day following the burn (T. Gonzalez, personal communication, 2009).

\subsection{Airborne Fourier Transform Infrared Spectrometer (AFTIR)}

The AFTIR on the Twin Otter was the same instrument as described by Yokelson et al. (2007b) but with improved optical stability due to the replacement of the adjustable closed-path tripled White cell with a new, permanently aligned $(78 \mathrm{~m}$ path), closed-path, uncoated, doubled, White cell (IR Analysis), and new, simplified transfer optics. The MIDAC ${ }^{1}$ spectrometer electronics were upgraded with an improved interferometer mirror-drive board, and a higher resolution dual analog-to-digital converter for data acquisition. The AFTIR detection limits ranged from 1-10 ppbv for most species for a 1-min spectral averaging time.

Ram air was collected through a forward-facing halocarbon wax coated inlet installed on the top of the aircraft. Immediately inside the aircraft, this inlet was connected to a $25 \mathrm{~mm}$ diameter PFA (perfluoroalkoxy) tube to direct the

\footnotetext{
${ }^{1}$ Trade names are provided for informational purposes only and do not constitute endorsement by the US Department of Agriculture.
} 
air through the White cell. Fast-acting, electronically activated valves located at the cell inlet and outlet were used to temporarily store the smoke sample within the cell to allow co-adding scans for increased sensitivity. The sampling procedure is thus somewhat analogous to grab sampling. The averaged grab sample spectra were analyzed either as single-beam spectra for those species with significant background concentrations (water $\left(\mathrm{H}_{2} \mathrm{O}\right)$, carbon dioxide $\left(\mathrm{CO}_{2}\right)$, carbon monoxide $(\mathrm{CO})$, and methane $\left(\mathrm{CH}_{4}\right)$ ) or transmission spectra referenced to an appropriate background spectrum, for the following gases with negligible background signals: ethyne $\left(\mathrm{C}_{2} \mathrm{H}_{2}\right)$, ethene $\left(\mathrm{C}_{2} \mathrm{H}_{4}\right)$, propene $\left(\mathrm{C}_{3} \mathrm{H}_{6}\right)$, formaldehyde $(\mathrm{HCHO})$, formic acid $(\mathrm{HCOOH})$, methanol $\left(\mathrm{CH}_{3} \mathrm{OH}\right)$, acetic acid $\left(\mathrm{CH}_{3} \mathrm{COOH}\right)$, furan $\left(\mathrm{C}_{4} \mathrm{H}_{4} \mathrm{O}\right)$, glycolaldehyde $\left(\mathrm{HOCH}_{2} \mathrm{CHO}\right)$, phenol $\left(\mathrm{C}_{6} \mathrm{H}_{5} \mathrm{OH}\right)$, hydrogen cyanide $(\mathrm{HCN})$, nitrous acid ( $\mathrm{HONO})$, ammonia $\left(\mathrm{NH}_{3}\right)$, peroxyacetyl nitrate $\left(\mathrm{PAN}, \mathrm{CH}_{3} \mathrm{COONO}_{2}\right)$ and ozone $\left(\mathrm{O}_{3}\right)$. The mixing ratios were obtained by multi-component fits to selected regions of the spectra with a synthetic calibration nonlinear least-squares method (Burling et al., 2010; Griffith, 1996; Yokelson et al., 2007a) utilizing both the HITRAN (Rothman et al., 2009) and Pacific Northwest National Laboratory (PNNL) (Johnson et al., 2006; Johnson et al., 2010; Sharpe et al., 2004) spectral databases. $\mathrm{NO}$ and $\mathrm{NO}_{2}$ were analyzed by peak integration of selected regions of their corresponding spectral features. The species above accounted for most of the features observed in the smoke spectra. For $\mathrm{NH}_{3}$ only, we corrected for losses on the cell walls as described in Yokelson et al. (2003). The PAN and $\mathrm{O}_{3}$ results are discussed elsewhere (Akagi et al., 2011a) as these are primarily products of plume aging.

\subsection{Particulate matter and nephelometry}

A large-diameter, fast-flow inlet adjacent to the AFTIR inlet supplied sample air for a Radiance Research Model 903 integrating nephelometer that measured $b_{\text {scat }}$ at $530 \mathrm{~nm}$ every 2 seconds. As discussed in (Yokelson et al., 2007b), gravimetric (filter-based) measurements of the mass of particles with aerodynamic diameter $<2.5 \mu \mathrm{m}\left(\mathrm{PM}_{2.5}\right)$ were compared to $\mathrm{b}_{\text {scat }}$ measurements during 14 fires in pine forest fuels burned in the US Forest Service Missoula fire simulation facility. This yielded a linear relationship between $\mathrm{b}_{\text {scat }}$ and $\mathrm{PM}_{2.5}$ in $\mu \mathrm{g} \mathrm{m}^{-3}$ of standard temperature and pressure air $(273 \mathrm{~K}, 1$ $\mathrm{atm})$, which we applied in this work for fresh smoke samples:

$\mathrm{PM}_{2.5}\left(\mu \mathrm{m}^{-3}\right)=b_{\text {scat }} \times 208800( \pm 11900(2 \sigma))$

This conversion factor is similar to the 250000 measured by Nance et al. (1993) for smoke from Alaskan wildfires in coniferous fuels, which they showed was within $\pm 20 \%$ of the factors determined in other studies of biomass burning smoke. In addition, an earlier study in the Missoula fire simulation facility, with fires in a larger variety of wildland fuels, found that the conversion factor of 250000 reproduced gravi- metric particle mass measurements within $\pm 12 \%$ (Trent et al., 2000).

The nephelometer inlet also provided sample air for a nondispersive infrared instrument (NDIR, LI-COR Model 6262) that provided continuous measurements of $\mathrm{CO}_{2}$ every $2 \mathrm{sec}$ onds. The $\mathrm{PM}_{2.5}$ for each plume penetration was integrated and compared to the integrated $\mathrm{CO}_{2}$ from the LI-COR to yield mass emission ratios of $\mathrm{PM}_{2.5}$ to $\mathrm{CO}_{2}$. The Twin Otter was also equipped with a single-particle soot-photometer (SP2, Droplet Measurement Technologies) and a compact time-of-flight aerosol mass spectrometer (c-ToF-AMS, Aerodyne, Inc.) for the California flights only. The results from these instruments will be published elsewhere.

\subsection{Land-based Fourier Transform Infrared Spectrometer (LaFTIR)}

Ground-based FTIR measurements of RSC were performed with our battery-powered mobile FTIR system (Christian et al., 2007). The optical bench is based on the same unmodified spectrometer (MIDAC 2500) and detector (Graseby FTIR-M16) as our airborne system but with a smaller, vibration isolated multipass White cell (Infrared Analysis, Inc. $16-\mathrm{V} ; 9 \mathrm{~m}$ pathlength) and a more compact geometry. Outside air is drawn through a $3 \mathrm{~m}$ section of $0.635 \mathrm{~cm}$ Teflon bellows tubing attached to a telescoping rod into the cell by a downstream diaphragm pump. A pair of manual Teflon shutoff valves allows trapping the sample in the cell for signal averaging. Temperature and pressure inside the cell are monitored in real time (Minco TT176 RTD, MKS Baratron 722A, respectively). Due to the shorter pathlength and other factors, the instrument detection limits ranged from $\sim 50-200 \mathrm{ppb}$ for most gases (Christian et al., 2007). However, this is generally sufficient for most species as much higher concentrations are sampled than in the lofted smoke (e.g. $>100 \mathrm{ppm}$ of $\mathrm{CO}$ in the ground-based samples as opposed to 1-15 ppm $\mathrm{CO}$ in the airborne samples). The samples were typically held in the cell for several minutes for signal averaging. The resulting stored spectrum was the average of 100 interferograms. The spectral quantification method was the same as that used in the AFTIR analysis, but with the additional quantification of 1,3-butadiene $\left(\mathrm{C}_{4} \mathrm{H}_{6}\right)$ and isoprene $\left(\mathrm{C}_{5} \mathrm{H}_{8}\right)$ gases. Several compounds that were observed in the AFTIR system $\left(\mathrm{HCOOH}\right.$, phenol, glycolaldehyde, PAN, $\mathrm{NO}, \mathrm{NO}_{2}$, and $\mathrm{HONO}$ ) were below the detection limits of the groundbased system.

\subsection{Airborne and ground-based sampling protocols}

During flight, the nephelometer, NDIR LI-COR, and the AFTIR were normally operated continuously in background air with similar time resolutions $(\sim 0.5-1 \mathrm{~Hz})$. At many key locations, the AFTIR acquired grab samples of background air. We acquired airborne smoke samples for most of the duration of the fire - from ignition until the smoke was no longer 
lofted. To measure the initial emissions from the fires, we sampled smoke less than several minutes old by penetrating the column of smoke $150-1000 \mathrm{~m}$ from the flame front. The goal of this sampling approach was to sample smoke that had already cooled to the ambient temperature since the chemical changes associated with smoke cooling are not explicitly included in most atmospheric models. This approach sampled smoke before most of the photochemical processing, which is explicitly included in most models. The NDIR $\mathrm{CO}_{2}$ and nephelometer ran continuously while penetrating the plume. The AFTIR was used to acquire grab samples in the smoke plumes. More than a few kilometers downwind from the source, smoke samples are usually already "photochemically aged" and better for probing post-emission chemistry than estimating initial emissions (Trentmann et al., 2003). Our work considers only the fresh smoke samples. Excess concentrations in the smoke plume grab samples were obtained from subtraction of background grab samples taken just outside the plume at a similar pressure and time (see Sect. 2.6).

After the initial flame front had passed through an area of the unit and flame-induced convection was no longer lofting the emissions, numerous spot sources of thick white smoke were typically observed contributing to a dense ground-level layer of smoke often confined below the canopy. The groundbased sampling consisted of acquiring FTIR snapshots of the emissions from as many scattered point sources as were accessible. A few sources were sampled multiple times to quantify their variability. The prescribed fires described in this work were purposely ignited under conditions where high surface fuel moistures would limit prolonged RSC so the production of smoke from the sources we sampled gradually decayed to insignificant levels within several hours.

\subsection{Emission ratio and emission factor calculations}

For chemical species quantified from the analysis of singlebeam spectra, excess mixing ratios above background (denoted as $\Delta X$ for any species " $X$ ") were calculated for each FTIR grab sample by subtraction of background values for those species. The transmission spectra intrinsically use ambient air as the background reference spectrum, so the mixing ratios calculated from fitting of these spectra are already excess values. Since we collected grab samples of the fresh smoke for nearly the entire duration of the fire, fire-average molar emission ratios (ER) were determined from the linear fit of a plot of $\Delta X$ vs. $\Delta Y$ (where $Y$ is often $\mathrm{CO}$ or $\mathrm{CO}_{2}$ ) for each fire with the intercept forced to zero (Yokelson et al., 1999). For those compounds that were measured with high signal-to-noise (e.g. $\mathrm{CO}, \mathrm{CO}_{2}, \mathrm{CH}_{3} \mathrm{OH}$, etc.) the standard error in the slope reflects the natural variation in ER (and subsequently EF) over the course of the fire. For these compounds the variability in the airborne samples was typically $<10 \%$. For those compounds measured with low signal-tonoise (e.g. glycolaldehyde, phenol) or for those fires where we obtained a limited number of grab samples from the air- craft (Bear Pen, Holly Shelter, Atmore, and Shaver) the uncertainty is significantly larger than the natural variability.

Since the emissions from flaming and smoldering processes are different, a useful quantity describing the relative amounts of flaming or smoldering combustion is the modified combustion efficiency (MCE), defined as (Yokelson et al., 1996):

$\mathrm{MCE}=\frac{\Delta \mathrm{CO}_{2}}{\Delta \mathrm{CO}_{2}}$

Higher MCE values indicate more flaming combustion whereas lower MCE values reflect more smoldering conditions, i.e. less complete oxidation.

Emission factors, $\mathrm{EF}(\mathrm{X})$ (grams of species X emitted per kilogram dry fuel burned) were calculated by the carbon mass-balance method (Burling et al., 2010; Nelson Jr., 1982; Yokelson et al., 1999). We assumed a carbon mass fraction $\left(F_{\mathrm{c}}\right)$ of $50 \%$ for the fuels burned here, an estimate based on the comprehensive work of Susott et al. (1996) and on measurements of similar fuel types (Burling et al., 2010; Ebeling and Jenkins, 1985). The actual fuel carbon percentage likely varied from this by less than a few percent. For the similar fuel types investigated by Burling et al. (2010), the percentages ranged from 48 to $55 \%$ carbon by mass. Emission factors scale linearly with the assumed fuel carbon fraction. We also assumed a particulate carbon mass fraction of $68.8 \%$ in our calculation of the total moles of carbon emitted (Ferek et al., 1998). Since the majority of the carbon mass ( $>98$ $99 \%$ ) is represented by the compounds $\mathrm{CO}_{2}, \mathrm{CO}$, and $\mathrm{CH}_{4}$ (all of which were measured by FTIR); considering only the carbon-containing compounds that are detected by the FTIR in the mass balance approach only inflates the emission factors by $\sim 1-2 \%$ (Yokelson et al., 2007b).

\section{Results and discussion}

The fire-average MCE and emission factors are shown in Tables 2 and 3 for the airborne samples of conifer forest understory and southwestern semi-arid fuels, respectively. The conifer forest understory fires include all NC fires and also the Shaver and Turtle fires of CA. The semi-arid SW burns include the CA chaparral fires and also the AZ oak savanna fire. For the airborne samples all emission factors are based on measurements made in smoke within a few kilometers of the fire. As the emissions of any particular species are often dependent on MCE, we also show the slope, y-intercept and correlation coefficients for the plots of $\mathrm{EF}(X)$ as a function of MCE for the two fuel types in Table 4. Those chemical species with negative slope (anti-correlated with MCE) are typically associated with smoldering combustion while those with positive slope (correlated with MCE) are usually products of flaming combustion. This generalization may not hold for those chemical species containing elements other than carbon, hydrogen or oxygen, as the emissions of those 
Table 2. Airborne emission factors $\left(\mathrm{g} \mathrm{kg}^{-1}\right)$ and MCE for conifer forest understory burns.

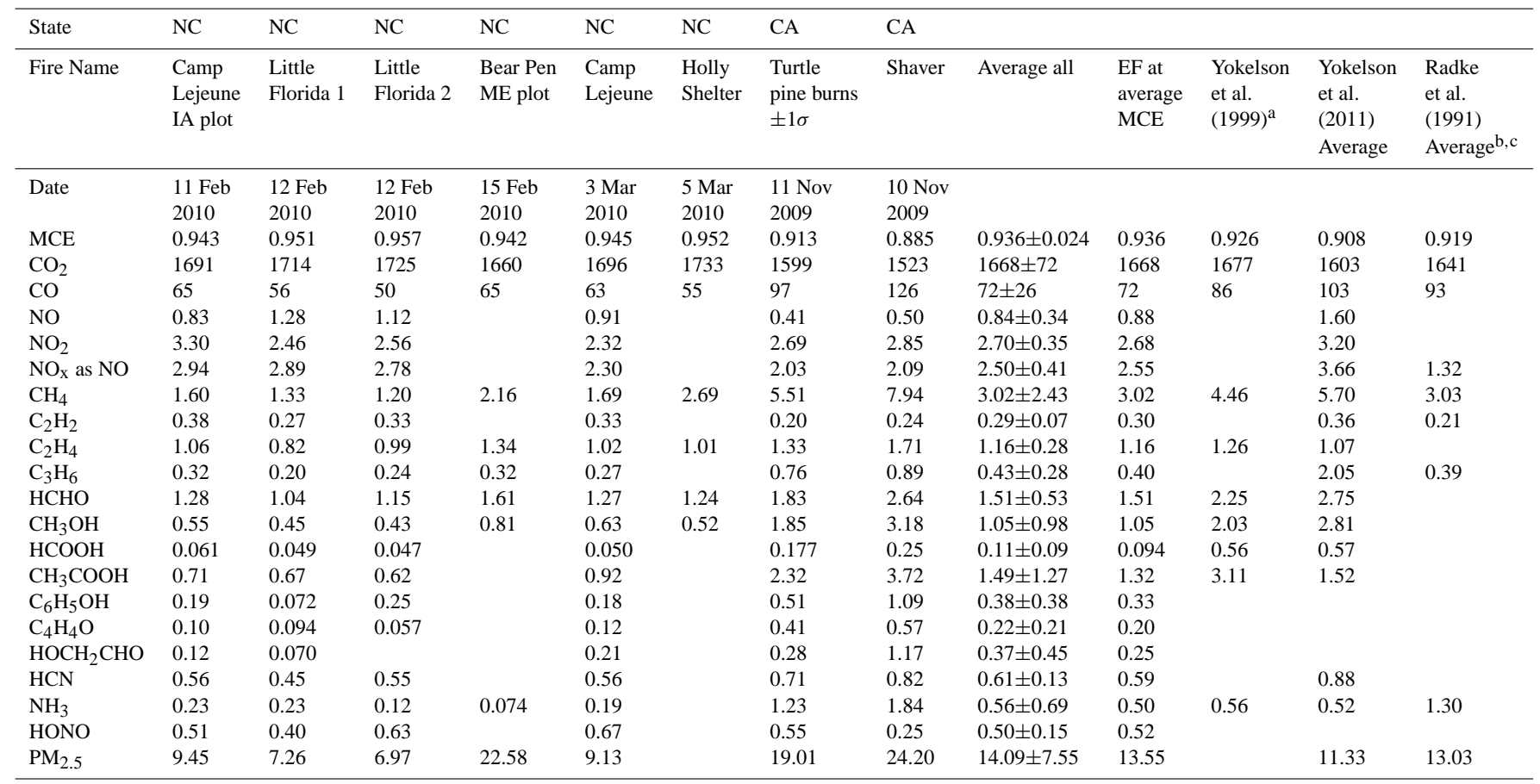

${ }^{\mathrm{a}} \mathrm{EF}(\mathrm{HCOOH})$ of Yokelson et al. (1999) is the corrected value (see text). ${ }^{\mathrm{b}} \mathrm{PM}$ of Radke et al. (1991) is $\mathrm{PM}_{3.5} .^{\mathrm{c}} \mathrm{NH}_{3}$ and $\mathrm{NO}_{\mathrm{x}}$ were measured in only 2 of the 3 coniferous fires of Radke et al. (1991) with an average MCE of 0.934.

species can also depend strongly on the elemental composition of the fuel.

\subsection{Emissions from understory fires in temperate coniferous forests}

All the fires sampled in NC and the Turtle and Shaver fires in CA were in forests with a coniferous (mostly pine) overstory, but burned mostly shrubs and grasses in the understory. As seen in Table 2, the airborne sampling of all the fires in NC revealed similar fire-average MCE $(0.949 \pm 0.006)$. The emission factors for the two CL burns (IA and ME) were quite similar for all emitted species with the exception of $\mathrm{NO}_{2}$. Although the ME burn was an overlapping sequence of different fuel types and treatments, the emission ratios were fairly consistent over time during this burn and thus are all considered as part of the same fire. This may have occurred because the smoke was mixed enough to make it impossible to distinguish the smoke from each individual fuel. The two CA fires both burned at lower MCE, allowing us to better assess the EF dependence on MCE. Table 2 shows the fire-average and study-average emission factors as measured from the airborne sampling platform for the individual fires of this fuel type. We also show the EF for each chemical species at the average MCE of all our conifer forest under- story burns based on the line of best fit (red line) of Fig. 1 and the fit statistics of Table 4 to compensate for any MCE differences for those species that were not detected in all fires. For comparison purposes, Table 2 also shows the study-average emissions factors for three other airborne studies of coniferous forest fires in rural areas: Radke et al. (1991) measured particulate and trace gas emissions from one prescribed and two wildfires in northwestern US coniferous fuels, possibly reflecting some consumption of canopy fuels. Due to the large intra-fire uncertainties in the Radke et al. (1991) coniferous emissions, we compare only to their average and standard deviation of the mean in the following discussion. Yokelson et al. (1999) reported EF for two prescribed understory fires at Camp Lejeune in pine forests in 1997. Finally, Yokelson et al. (2011) sampled fires in pine-oak forests in rural Mexico: about half of their fires were deforestation fires and thus consumed significant amounts of large diameter logs.

A range of study-average MCE was observed in the studies of coniferous forest fires. Our study average MCE was 0.936. Yokelson et al. (1999) observed slightly lower MCE (0.926) for their NC fires, Radke et al. (1991) report 0.919, and Yokelson et al. (2011), 0.908. Since EF (and MCE) depend on the flaming to smoldering ratio, some variation in $\mathrm{EF}$ between studies occurs because fires with different average 
Table 3. Airborne emission factors $\left(\mathrm{g} \mathrm{kg}^{-1}\right)$ and MCE for chaparral ${ }^{\mathrm{a}}$ and Emory oak savanna burns in the southwestern US.

\begin{tabular}{|c|c|c|c|c|c|c|c|c|c|}
\hline State & $\mathrm{CA}$ & $\mathrm{CA}$ & $\mathrm{CA}$ & $\mathrm{CA}$ & $\mathrm{CA}$ & $\mathrm{AZ}$ & & $\mathrm{CA}$ & $\mathrm{CA}$ \\
\hline Fire Name & $\begin{array}{c}\text { Test fire } \\
\text { Grant block A }\end{array}$ & $\begin{array}{c}\text { Grant } \\
\text { block A }\end{array}$ & $\begin{array}{c}\text { Grant } \\
\text { block B }\end{array}$ & $\begin{array}{l}\text { Williams } \\
\text { Fire }\end{array}$ & $\begin{array}{l}\text { Atmore } \\
\text { Fire }\end{array}$ & $\begin{array}{l}\text { Fort Huachuca } \\
\text { T2 plot }\end{array}$ & $\begin{array}{c}\text { Average }( \pm 1 \sigma) \\
\text { all semi-arid } \\
\text { southwest }\end{array}$ & $\begin{array}{l}\text { Radke et al. } \\
\qquad(1991) \\
\text { Average }^{b, c}\end{array}$ & $\begin{array}{c}\text { Hardy et al. } \\
\text { (1996) } \\
\text { Average }\end{array}$ \\
\hline Date & 5 Nov 2009 & 11 Nov 2009 & 11 Nov 2009 & 17 Nov 2009 & 18 Nov 2009 & $25 \operatorname{Mar} 2010$ & & & \\
\hline MCE & 0.950 & 0.938 & 0.903 & 0.933 & 0.947 & 0.940 & $0.935 \pm 0.017$ & 0.946 & 0.925 \\
\hline $\mathrm{CO}_{2}$ & 1709 & 1679 & 1603 & 1666 & 1705 & 1681 & $1674 \pm 38$ & 1687 & 1617 \\
\hline $\mathrm{CO}$ & 58 & 70 & 109 & 76 & 61 & 69 & $74 \pm 18$ & 61 & 83 \\
\hline NO & 0.95 & 0.57 & 0.41 & 0.93 & & 0.87 & $0.75 \pm 0.24$ & & \\
\hline $\mathrm{NO}_{2}$ & 1.76 & 2.55 & 1.56 & 2.86 & 2.28 & 4.48 & $2.58 \pm 1.05$ & & \\
\hline $\mathrm{NO}_{\mathrm{x}}$ as $\mathrm{NO}$ & 2.08 & 2.17 & 1.29 & 2.62 & 1.49 & 3.42 & $2.18 \pm 0.78$ & 5.11 & \\
\hline $\mathrm{CH}_{4}$ & 2.37 & 3.34 & 6.31 & 3.77 & 3.10 & 3.23 & $3.69 \pm 1.36$ & 2.30 & 3.24 \\
\hline $\mathrm{C}_{2} \mathrm{H}_{2}$ & 0.25 & 0.28 & 0.19 & 0.19 & 0.18 & 0.19 & $0.21 \pm 0.04$ & 0.20 & \\
\hline $\mathrm{C}_{2} \mathrm{H}_{4}$ & 0.89 & 1.30 & 1.21 & 0.97 & 0.79 & 0.91 & $1.01 \pm 0.2$ & & \\
\hline $\mathrm{C}_{3} \mathrm{H}_{6}$ & 0.36 & 0.51 & 0.95 & 0.54 & 0.42 & 0.41 & $0.53 \pm 0.22$ & 0.43 & \\
\hline $\mathrm{HCHO}$ & 1.22 & 1.63 & 1.22 & 1.34 & 1.08 & 1.48 & $1.33 \pm 0.2$ & & \\
\hline $\mathrm{CH}_{3} \mathrm{OH}$ & 0.84 & 1.15 & 1.95 & 1.45 & 1.08 & 1.61 & $1.34 \pm 0.4$ & & \\
\hline $\mathrm{HCOOH}$ & 0.039 & 0.082 & 0.020 & 0.082 & 0.0020 & 0.24 & $0.078 \pm 0.087$ & & \\
\hline $\mathrm{CH}_{3} \mathrm{COOH}$ & 1.49 & 2.17 & 1.76 & 2.29 & 0.47 & 3.29 & $1.91 \pm 0.93$ & & \\
\hline $\mathrm{C}_{6} \mathrm{H}_{5} \mathrm{OH}$ & 0.21 & 0.30 & 0.65 & 0.38 & 0.69 & 0.49 & $0.45 \pm 0.19$ & & \\
\hline $\mathrm{C}_{4} \mathrm{H}_{4} \mathrm{O}$ & 0.19 & 0.23 & 0.57 & 0.27 & 0.21 & 0.34 & $0.30 \pm 0.14$ & & \\
\hline $\mathrm{HOCH}_{2} \mathrm{CHO}$ & 0.27 & 0.40 & & 0.007 & & 0.33 & $0.25 \pm 0.17$ & & \\
\hline $\mathrm{HCN}$ & 0.52 & 0.65 & 0.99 & 0.95 & 0.41 & 0.97 & $0.75 \pm 0.26$ & & \\
\hline $\mathrm{NH}_{3}$ & 0.52 & 1.13 & 4.24 & 1.76 & 0.41 & 0.95 & $1.50 \pm 1.43$ & 0.90 & \\
\hline HONO & 0.71 & 0.70 & 0.36 & 0.51 & 0.50 & 0.43 & $0.54 \pm 0.14$ & & \\
\hline $\mathrm{PM}_{2.5}$ & 5.95 & 7.49 & 8.66 & 8.59 & 4.86 & 6.83 & $7.06 \pm 1.5$ & 15.93 & 8.98 \\
\hline
\end{tabular}

${ }^{a}$ Coastal sage scrub and maritime chaparral. ${ }^{b} \mathrm{PM}$ of Radke et al. (1991) is $\mathrm{PM}_{3.5}{ }^{\mathrm{c}} \mathrm{NH}_{3}$ and was measured in only 2 of the 3 chaparral fires of Radke et al. (1991) with an average MCE of 0.934 .

Table 4. Statistics for the linear regression of EF as a function of MCE for conifer forest understory burns and the semi-arid burns of the southwest (chaparral and oak savanna). Values in parentheses represent one standard deviation $(1 \sigma)$.

\begin{tabular}{l|ccc|ccc}
\hline & & Conifer forest understory & & \multicolumn{3}{c}{ Semi-arid southwest } \\
\hline & Slope & y-intercept & $R^{2}$ & Slope & y-intercept & $R^{2}$ \\
\hline $\mathrm{NO}$ & $10.5(3.2)$ & $-8.9(3)$ & 0.72 & $10.8(5)$ & $-9.3(4.7)$ & 0.61 \\
$\mathrm{NO}_{2}$ & $-3.5(6)$ & $6(5.6)$ & 0.08 & $18.0(30.2)$ & $-14.3(28.3)$ & 0.08 \\
$\mathrm{NO}_{\mathrm{x}}$ as NO & $11.7(4.7)$ & $-8.4(4.4)$ & 0.60 & $17.1(21.7)$ & $-13.8(20.3)$ & 0.13 \\
$\mathrm{CH}_{4}$ & $-96(10.1)$ & $92.9(9.5)$ & 0.94 & $-81.2(5.4)$ & $79.7(5.1)$ & 0.98 \\
$\mathrm{C}_{2} \mathrm{H}_{2}$ & $1.6(0.9)$ & $-1.2(0.8)$ & 0.44 & $0.7(1.2)$ & $-0.5(1.1)$ & 0.09 \\
$\mathrm{C}_{2} \mathrm{H}_{4}$ & $-10.5(2)$ & $10.9(1.9)$ & 0.82 & $-7.4(4.8)$ & $7.9(4.5)$ & 0.37 \\
$\mathrm{C}_{3} \mathrm{H}_{6}$ & $-10.6(1.1)$ & $10.3(1)$ & 0.95 & $-12.8(1.1)$ & $12.5(1)$ & 0.97 \\
$\mathrm{HCHO}$ & $-20.7(2.3)$ & $20.9(2.1)$ & 0.93 & $0.5(6)$ & $0.8(5.6)$ & 0.00 \\
$\mathrm{CH}_{3} \mathrm{OH}$ & $-39.6(2.4)$ & $38.1(2.2)$ & 0.98 & $-21(5.9)$ & $21(5.5)$ & 0.76 \\
$\mathrm{HCOOH}$ & $-3.1(0.2)$ & $3(0.2)$ & 0.98 & $0.8(2.6)$ & $-0.7(2.4)$ & 0.02 \\
$\mathrm{CH}_{3} \mathrm{COOH}$ & $-45.5(3.3)$ & $43.9(3.1)$ & 0.98 & $-8.4(27.8)$ & $9.7(26)$ & 0.02 \\
$\mathrm{C}_{6} \mathrm{H}_{5} \mathrm{OH}$ & $-13(2.1)$ & $12.5(2)$ & 0.91 & $-5.2(5.1)$ & $5.3(4.8)$ & 0.20 \\
$\mathrm{C}_{4} \mathrm{H}_{4} \mathrm{O}$ & $-7.6(0.5)$ & $7.3(0.5)$ & 0.98 & $-8.1(1.3)$ & $7.9(1.2)$ & 0.90 \\
$\mathrm{HOCH}$ & $-15.0(3.8)$ & $14.2(3.5)$ & 0.84 & $11.2(16.0)$ & $-10.3(15.0)$ & 0.20 \\
$\mathrm{HCN}$ & $-4.6(0.8)$ & $4.9(0.7)$ & 0.90 & $-10.6(5.6)$ & $10.6(5.2)$ & 0.47 \\
$\mathrm{NH}_{3}$ & $-26.5(2.7)$ & $25.3(2.5)$ & 0.95 & $-85.3(4.8)$ & $81.3(4.5)$ & 0.99 \\
$\mathrm{HONO}$ & $3.7(2.1)$ & $-3(1.9)$ & 0.45 & $5.6(3.3)$ & $-4.7(3.1)$ & 0.42 \\
$\mathrm{PM}_{2.5}$ & $-231(83)$ & $230(78)$ & 0.61 & $-68(29)$ & $71(27)$ & 0.58 \\
\hline
\end{tabular}



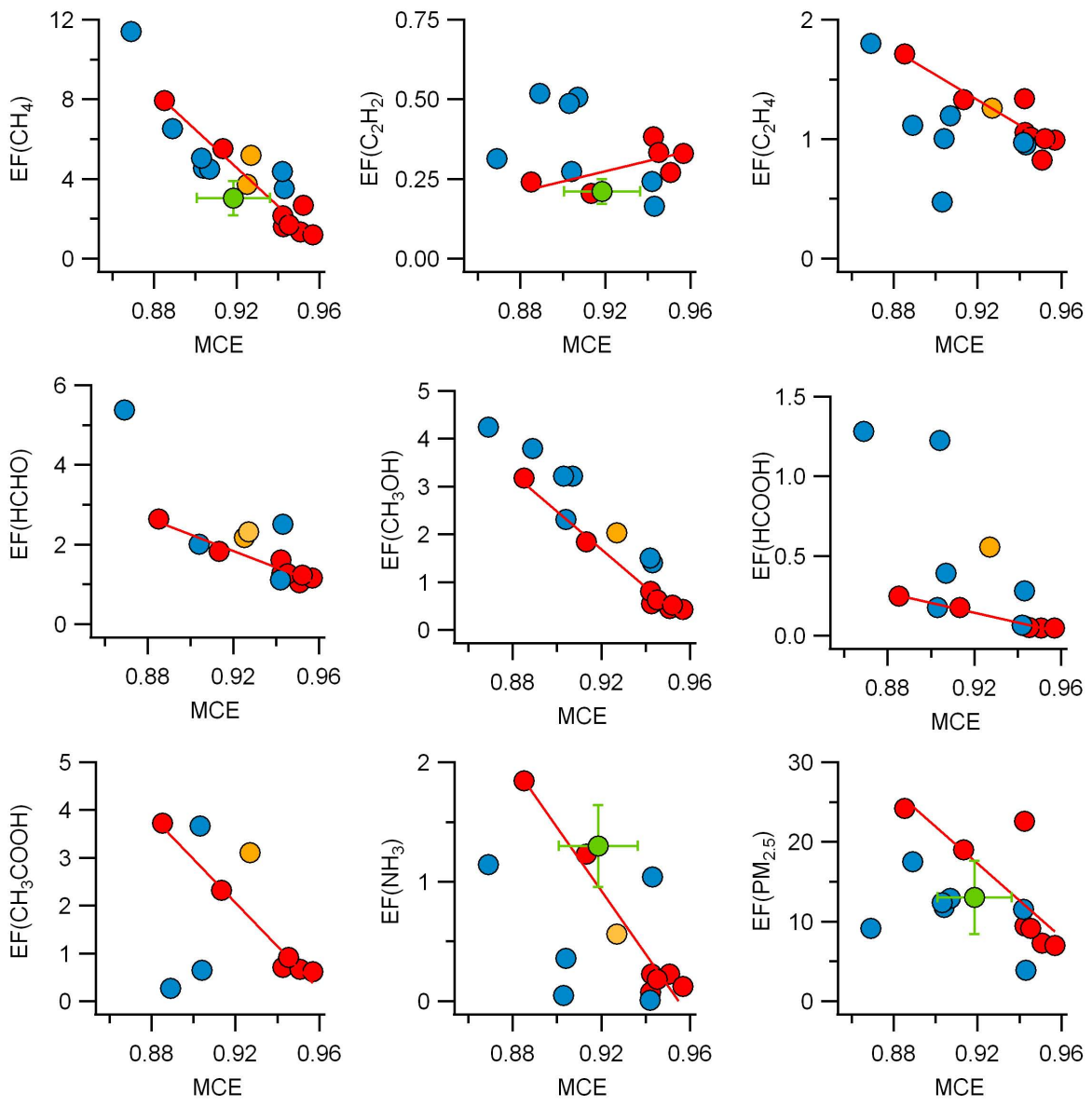

$$
\begin{array}{|ll|}
\hline \text { This work } & \text { O Yokelson et al. (1999) } \\
\text { Mexico pine (Yokelson et al., 2011) } & \text { O Radke et al. (1991) } \\
\hline
\end{array}
$$

Fig. 1. Emission factors $\left(\mathrm{g} \mathrm{kg}^{-1}\right)$ as a function of MCE for the conifer forest understory burns of this study (red circles). We also show the NC pine forest understory data of Yokelson et al. (1999), rural Mexico pine-oak data of Yokelson et al. (2011), and Radke et al. (1991). We show only the average and standard deviation of the Radke et al. (1991) data due to the high variability. Regression statistics are shown in Table 4 and apply only to the data collected in this work.

flaming to smoldering ratios were sampled. Thus, when possible, we compare the fits of EF vs. MCE between studies.

Methane is the most abundant organic gas-phase emission from biomass burning and its emission from fires has a significant impact on the global levels of this greenhouse gas (Simpson et al., 2006). Our fire-average $\mathrm{EF}\left(\mathrm{CH}_{4}\right)$ for US conifer understory burns was $3.02 \mathrm{~g} \mathrm{~kg}^{-1}$ at an average MCE of 0.936 and all $\mathrm{EF}$ lie close to the regression line $\left(R^{2}=0.94\right)$ of $\mathrm{EF}\left(\mathrm{CH}_{4}\right)$ vs. MCE (Fig. 1). Yokelson et al. (1999) observed an average $\mathrm{EF}\left(\mathrm{CH}_{4}\right)$ of $4.46 \mathrm{~g} \mathrm{~kg}^{-1}$, which is consistent with our $\mathrm{EF}\left(\mathrm{CH}_{4}\right)$ vs. MCE fit. The $\mathrm{EF}\left(\mathrm{CH}_{4}\right)$ data points of Yokelson et al. (2011) and Radke et al. (1991) also lie close to our fit. Methane and methanol are the two species for which all the airborne measurements in temperate conifer forests (US and Mexico) lay near the same EF vs. MCE fit (Fig. 1).
The NMHC species measured in these studies tend to exhibit more variability both between and within studies. Ethyne has a slightly positive correlation with MCE, while appearing weakly anti-correlated with MCE in Yokelson et al. (2011). This is not surprising since $\mathrm{C}_{2} \mathrm{H}_{2}$ is mostly produced by flaming combustion but can also be produced by smoldering combustion. Due to variability in its emissions the dominant correlation with flaming may only be more evident when a wider range of MCE is considered (e.g. Fig. 3 in Yokelson et al., 2008). For ethene, the North Carolina $\mathrm{EF}\left(\mathrm{C}_{2} \mathrm{H}_{4}\right)$ from Yokelson et al. (1999) lies on our regression line (Fig. 1). On the other hand, the $\mathrm{EF}\left(\mathrm{C}_{2} \mathrm{H}_{4}\right)$ values for Mexican pine forest fires by Yokelson et al. (2011) are much more scattered and lower than those observed in the US perhaps partly due to fuel differences. Our $\mathrm{EF}\left(\mathrm{C}_{3} \mathrm{H}_{6}\right)$ as a function of MCE (Table 4) is well represented by a straight line with an $R^{2}$ of 0.95 . With the exception of $\mathrm{C}_{2} \mathrm{H}_{2}$, all 
hydrocarbons measured here were observed to be consistent with emission from smoldering combustion.

Biomass burning is also a significant source of oxygenated volatile organic compounds (OVOC) (Yokelson et al., 1999) which strongly influence the atmosphere as a source of oxidants (Singh et al., 1995) and also impact photochemical ozone production (Trentmann et al., 2005) and secondary organic aerosol (SOA) formation in aging biomass burning plumes (Aiken et al., 2008; Hennigan et al., 2008; Yokelson et al., 2009). In our study, we detected the more volatile low molecular weight species. For example, formaldehyde, an air toxin, an oxidant in cloud droplets, and an important precursor of photochemical $\mathrm{O}_{3}$ production, is emitted by biomass burning and was detected by our AFTIR. The fire-average $\mathrm{EF}(\mathrm{HCHO})$ for the two Camp Lejeune burns in this study were remarkably similar, with values of 1.28 and $1.27 \mathrm{~g} \mathrm{~kg}^{-1}$ (MCE $=0.944$ and 0.946) for the IA and ME burns (respectively), even though these were burns of slightly different fuels and occurred several weeks apart. The average $\mathrm{EF}(\mathrm{HCHO})$ for all conifer forest understory fires in our study was $1.51 \mathrm{~g} \mathrm{~kg}^{-1}$. In comparison, Yokelson et al. (1999) obtained an average value for $\mathrm{EF}(\mathrm{HCHO})$ at Camp Lejeune of $2.25 \mathrm{~g} \mathrm{~kg}^{-1}$. Using our $\mathrm{EF}(\mathrm{HCHO})$ vs. MCE regression (Fig. 1 and Table 4) to calculate an EF at the Yokelson et al. (1999) MCE yields an $\mathrm{EF}(\mathrm{HCHO})$ value of $1.7 \mathrm{~g} \mathrm{~kg}^{-1}$, a value slightly lower than that of Yokelson et al. (1999). With the exception of one fire at low MCE, the $\mathrm{EF}(\mathrm{HCHO})$ data for Mexican pine forest fires (Yokelson et al., 2011) are consistent with this trend.

Yokelson et al. (1999) reported $\mathrm{EF}(\mathrm{HCOOH})$ measured at Camp Lejeune of $1.17 \mathrm{~g} \mathrm{~kg}^{-1}$. Dividing their $\mathrm{EF}(\mathrm{HCOOH})$ by 2.1 to reflect recent improvements in the absorption line parameters for $\mathrm{HCOOH}$ (Perrin and Vander Auwera, 2007) yields a corrected $\mathrm{EF}(\mathrm{HCOOH})$ of $0.56 \mathrm{~g} \mathrm{~kg}^{-1}$. This $\mathrm{EF}$ is still much higher than our conifer understory fire-averaged value of $\mathrm{EF}(\mathrm{HCOOH})$ of $0.094 \mathrm{~g} \mathrm{~kg}^{-1}\left(0.12 \mathrm{~g} \mathrm{~kg}^{-1}\right.$ at MCE of 0.926) and the difference may be due to the presence of a larger component of logs (caused by hurricane blowdown in 1996) in the understory during the 1997 measurements. Four of the six $\mathrm{EF}(\mathrm{HCOOH})$ values measured in rural Mexican pine forest fires (Yokelson et al., 2011) are fairly close to our fit line, but two are much higher. The high Mexican EF measurements were on deforestation fires in Chiapas and so also probed emissions from fuels that contained more large downed logs. As noted above, for methanol the EF from all studies lie close to the fit for our data. For $\mathrm{CH}_{3} \mathrm{COOH}$, the other measurement at Camp Lejeune lies close to the line, but two of the three Mexico EF lie well below, with only one of the low EF being from a deforestation fire.

Glycolaldehyde is a small organic with two functional groups and also a precursor for production of several of the above compounds including formaldehyde, formic acid, and glyoxal (Butkovskaya et al., 2006). Moreover, hydroxyl radical-initiated aqueous photo-oxidation of glycolaldehyde may yield low volatility products leading to secondary or- ganic aerosol formation (Perri et al., 2009). Glycolaldehyde has previously been observed as a product of smoldering combustion in studies of laboratory biomass fires (e.g. Yokelson et al., 1997). Out of the 14 fires we sampled, the highest value of $\mathrm{EF}\left(\mathrm{HOCH}_{2} \mathrm{CHO}\right)\left(1.17 \mathrm{~g} \mathrm{~kg}^{-1}\right)$ was observed in the Shaver fire, the conifer forest understory fire with the lowest MCE (0.885). We observed fairly good anti-correlation of $\mathrm{EF}\left(\mathrm{HOCH}_{2} \mathrm{CHO}\right)$ with $\mathrm{MCE}$ for our conifer forest understory burns $\left(R^{2}=0.86\right)$. To our knowledge, these observations represent the first field measurements of glycolaldehyde emissions from fires.

We also report field measurements of furan and phenol emissions from temperate coniferous forest fires. The atmospheric impact of fire emissions of these species was discussed by Bertschi et al. (2003) and Mason et al. (2001). In addition, phenol is of interest as a precursor for aqueous phase SOA. Our airborne EF for phenol and furan for conifer forest fires are within $12 \%$ and $33 \%$ (respectively) of the EF measured from the air for tropical forest fires (Yokelson et al., 2008). Those authors observed much higher emissions of these species from ground-based field measurements of RSC; a theme discussed below.

Ammonia is the most abundant alkaline gas in the atmosphere and is important in neutralizing acidic species in particulate matter (Seinfeld and Pandis, 1998). Yokelson et al. (1999) observed an $\mathrm{EF}\left(\mathrm{NH}_{3}\right)$ of $0.56 \mathrm{~g} \mathrm{~kg}^{-1}$ at Camp Lejeune, which is identical to our average value for US conifer forest fires. Our fit predicts an $\mathrm{EF}\left(\mathrm{NH}_{3}\right)$ of $0.76 \mathrm{~g} \mathrm{~kg}^{-1}$ (within $25 \%$ ) at the Yokelson et al. (1999) MCE of 0.926. While our study and those of Yokelson et al. (1999) and Radke et al. (1991) are all consistent with our $\mathrm{EF}\left(\mathrm{NH}_{3}\right)$ vs. MCE fit, three of the five $\mathrm{EF}\left(\mathrm{NH}_{3}\right)$ observed by Yokelson et al. (2011) in Mexico lie below our line with two of these three being deforestation fires (Fig. 1). Although $\mathrm{NH}_{3}$ is a product of smoldering combustion, its emissions are also dependent on the nitrogen content of the vegetation, which although unknown in these studies, tends to be lower in woody biomass (e.g. logs) than in foliage.

Biomass burning particulate matter $\left(\mathrm{PM}_{2.5}\right)$ is mostly composed of organic aerosol, a product of smoldering combustion (Reid et al., 2005). In our study, the MCE and $\mathrm{EF}\left(\mathrm{PM}_{2.5}\right)$ of the $\mathrm{NC}$ burns were fairly similar for all burns with the exception of the Bear Pen fire of 15 February 2010 with an $\operatorname{EF}\left(\mathrm{PM}_{2.5}\right)$ more than double the next highest value despite having similar MCE. This fire was influenced by very strong surface winds, keeping the smoke close to the ground, making airborne sampling difficult. These strong winds may have influenced $\mathrm{EF}\left(\mathrm{PM}_{2.5}\right)$. With the exception of this fire, the $\mathrm{EF}\left(\mathrm{PM}_{2.5}\right)$ as a function of MCE are all close to the line of best fit. In the other airborne study of US coniferous forest fires that reports $\mathrm{EF}(\mathrm{PM})$, Radke et al. (1991) report an average $\mathrm{EF}\left(\mathrm{PM}_{3.5}\right)$ that lies close to our fit. In general, $\mathrm{EF}\left(\mathrm{PM}_{3.5}\right)$ is not expected to differ greatly from $\mathrm{EF}\left(\mathrm{PM}_{2.5}\right)$ since most of the PM emitted in biomass burning smoke is below $1 \mu \mathrm{m}$ (Reid et al., 2005). Five of the six $\operatorname{EF}\left(\mathrm{PM}_{2.5}\right)$ 

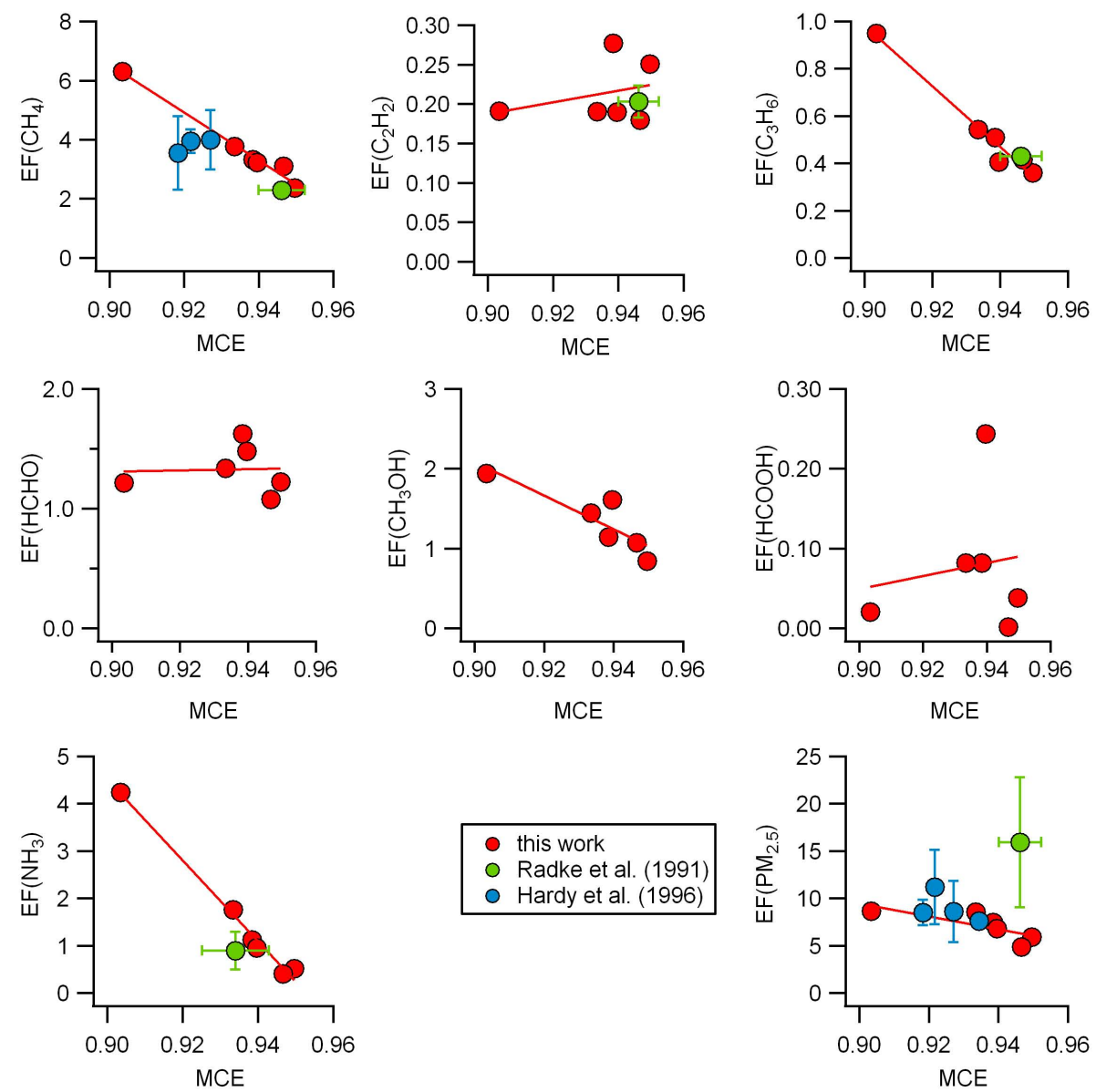

Fig. 2. Emission factors $\left(\mathrm{g} \mathrm{kg}^{-1}\right)$ as a function of MCE for chaparral (coastal sage scrub and maritime chaparral) and oak savanna fires of this study as well as Radke et al. (1991) and Hardy et al. (1996) (interior chaparral). Regression statistics are shown in Table 4. $\mathrm{NH}_{3}$ was measured in only two of the three chaparral fires of Radke et al. (1991). The MCE and $\mathrm{EF}\left(\mathrm{NH}_{3}\right)$ are based on these two fires $(\mathrm{MCE}=0.934)$. The PM of Radke et al. (1991) is of $\mathrm{PM}_{3.5}$. Regression statistics are shown in Table 4 and apply only to the data collected in this work.

points of Yokelson et al. (2011) from Mexico are 10-50\% below our best-fit line and one (at the lowest MCE) is well below our line. However, the study averages for Mexican pine forest fires $\left(11.3 \pm 4.1 \mathrm{~g} \mathrm{~kg}^{-1}\right)$ and our conifer forest understory fires $\left(14.1 \pm 7.6 \mathrm{~g} \mathrm{~kg}^{-1}\right)$ are within $20 \%$. The fractional standard deviation in the average of the Mexican values is lower, but the Mexican emission factors are actually less correlated with MCE. This could reflect the more diverse fuels and the unregulated nature of the Mexican fires.

In general, our emission factors for all organic species are well-represented by a straight line as a function of MCE (Figs. 1 and 2). Of the nitrogen-containing species, $\mathrm{NH}_{3}$ and HCN are well anti-correlated with MCE while the flaming combustion products $\mathrm{NO}_{\mathrm{x}}$ and HONO (Roberts et al., 2010; Veres et al., 2010) are fairly well-correlated. In addition to MCE, the emissions of these species will also depend on the nitrogen content of the fuels, which is unknown in this study.

\subsection{Emissions from chaparral fires}

There has been relatively little previous field work investigating the emissions from chaparral fires. Hardy et al. (1996) (tower-based) and Radke et al. (1991) (aircraft) published emission factors for a limited number of trace gas species and particulate matter for prescribed chaparral fires. Another important fire-adapted ecosystem in the semi-arid southwestern US is oak savanna. While not consumed in the AZ oak savanna fire, several species of Arctostaphylos occur in both Madrean oak woodland and in California chaparral as well as the understory of the two coniferous fires sampled in the Sierra Nevada. To our knowledge there are no previous field measurements of the emissions from fires in this land cover type. We present our emission factors for all the CA chaparral fires and the AZ oak savanna fire in Table 3. We also show the study average EF for all these southwestern fires as a group. Including the oak savanna fire with the chaparral fires is justified here because the emission factors for the oak 
savanna are mostly consistent with the regression lines of EF vs. MCE (with the exceptions of $\mathrm{HCOOH}, \mathrm{CH}_{3} \mathrm{COOH}$, and $\mathrm{NO}_{2}$ as discussed below) which are driven almost completely by the chaparral fires (Fig. 2). For comparison purposes, we also show study average EF for two other field studies of chaparral fires in Table 3. Graphs of EF as a function of MCE for selected chemical species that were also measured in the previous field studies are shown in Fig. 2 and the linear regression fit statistics for all species measured in this study are shown in Table 4.

The chaparral fires of the studies we compare to burned with similar flaming and smoldering fractions. The average MCE for our five chaparral burns plus one oak savanna fire was $0.935 \pm 0.017$, spanning a range from 0.903 to 0.950 , while the average MCE of the Radke et al. (1991) and Hardy et al. (1996) studies were 0.946 and 0.925 , respectively.

The $\mathrm{EF}\left(\mathrm{CH}_{4}\right)$ in our study are well described as a linear function of MCE $\left(R^{2}=0.98\right)$ (Fig. 2). The $\mathrm{EF}\left(\mathrm{CH}_{4}\right)$ points of Radke et al. (1991) and Hardy et al. (1996) also lie close to this regression line. Our $\mathrm{EF}\left(\mathrm{C}_{2} \mathrm{H}_{2}\right)$ plot shows little correlation with MCE for reasons discussed earlier. The $\mathrm{EF}\left(\mathrm{C}_{2} \mathrm{H}_{2}\right)$ study average of Radke et al. (1991) agrees very well with our data (Fig. 2). The $\mathrm{EF}\left(\mathrm{C}_{3} \mathrm{H}_{6}\right)$ points of our study and Radke et al. (1991) are both close to the line of best fit of our study. Hardy et al. (1996) did not speciate individual NMHC and instead reported an EF(NMHC) for the chaparral fires observed in their study. Their average EF(NMHC) was $9.36 \pm 6.9 \mathrm{~g} \mathrm{~kg}^{-1}$. Since we only measured three NMHC species, our $\mathrm{EF}(\mathrm{NMHC})$ of $4.05 \pm 0.96 \mathrm{~g} \mathrm{~kg}^{-1}$ is lower but within the uncertainty.

The linear regression fits for the OVOC species are strongly influenced by the Grant B fire, which burned at the lowest MCE of the chaparral fuels. For HCHO (Fig. 2), with the exception of the Grant B burn, $\mathrm{EF}(\mathrm{HCHO})$ is anti-correlated with MCE (indicating smoldering) but inclusion of the Grant B point essentially removes the anticorrelation of $\mathrm{EF}(\mathrm{HCHO})$ with MCE. This effect also occurs for $\mathrm{HCOOH}$ (Fig. 2) and to a lesser extent $\mathrm{CH}_{3} \mathrm{COOH}$. Because of the sensitivity to the low MCE point, the possibility exists that acquisition of more data at low MCE would significantly change the fit. The $\mathrm{EF}\left(\mathrm{CH}_{3} \mathrm{OH}\right)$ (Fig. 2) and $\mathrm{EF}\left(\mathrm{C}_{4} \mathrm{H}_{4} \mathrm{O}\right)$ vs. MCE show good agreement for all the fires with the line of best fit $\left(R^{2}=0.76\right.$ and 0.90 , respectively).

Radke et al. (1991) also measured the nitrogen-containing species $\mathrm{NO}_{\mathrm{x}}$ and $\mathrm{NH}_{3}$. Our average $\mathrm{EF}\left(\mathrm{NO}_{\mathrm{x}}\right.$ as $\mathrm{NO}$ ) $\left(2.03 \pm 0.78 \mathrm{~g} \mathrm{~kg}^{-1}\right)$ is less than half that of Radke et al. (1991) $\left(5.1 \pm 1.37 \mathrm{~g} \mathrm{~kg}^{-1}\right)$. The higher $\mathrm{EF}\left(\mathrm{NO}_{\mathrm{x}}\right.$ as NO) of Radke et al. (1991) is not surprising since some of the chaparral fires sampled by Radke et al. (1991) were located in the San Dimas Experimental Forest which is significantly impacted by nitrogen deposition associated with the urban air pollution generated in the nearby Los Angeles airshed (Hegg et al., 1987). Hegg et al. (1987) compared their nitrogen emissions from San Dimas chaparral fires to the nitrogen emissions from fires in coniferous slash in rural areas of the US and suggested that the enhanced nitrogen emissions from the San Dimas fires could be due to nitrogen deposition. However, they could not rule out the possibility that fuel differences contributed to the observed differences in emissions (e.g. different ability to support active nitrogen fixation or variable foliage consumption between the various plant species). Here we directly confirm that the $\mathrm{NO}_{\mathrm{x}}$ emissions from our rural chaparral fires are significantly lower than the reported $\mathrm{NO}_{\mathrm{x}}$ emissions from urban-impacted chaparral fires. Recently, Yokelson et al. (2011) showed that $\mathrm{NO}_{\mathrm{x}}$ emissions from rural pine-forest fires were half those from pine forest fires adjacent to the Mexico City metropoli$\tan$ area. The data in this paper also confirm the lower $\mathrm{NO}_{\mathrm{x}}$ emissions from rural pine forest fires. The impact of urban deposition on nearby open burning could be important to include in some model applications since $\mathrm{NO}_{\mathrm{x}}$ emissions also strongly impact the post-emission formation of ozone and SOA (Alvarado and Prinn, 2009; Grieshop et al., 2009; Trentmann et al., 2005).

For ammonia, the EF vs. MCE plot of our data has an excellent $R^{2}(0.99)$ and $\mathrm{EF}\left(\mathrm{NH}_{3}\right)$ is strongly anti-correlated with MCE. The average $\mathrm{EF}\left(\mathrm{NH}_{3}\right)$ of Radke et al. (1991) lies close to our best fit line (Fig. 2). The average value shown by Radke et al. (1991) (also shown in Hegg et al., 1988) obscures the fact that these authors actually observed highly variable $\mathrm{NH}_{3}$ emissions for their Lodi 1 and Lodi 2 chaparral fires. These two burns were of similar fuel types but were burned several months apart so the difference in $\mathrm{NH}_{3}$ emissions was attributed to different environments, particularly fuel and soil moisture. The fire with the higher $\mathrm{EF}\left(\mathrm{NH}_{3}\right)$ was impacted by recent rainfall (Hegg et al., 1988). The authors speculated that the high fuel moisture from the recent rainfall moderated soil heating (pyrolysis) which favored $\mathrm{NH}_{3}$ over $\mathrm{NO}_{\mathrm{x}}$ emission, since $\mathrm{NO}_{\mathrm{x}}$ is a flaming combustion product. In contrast, in this work the Grant Block A fires actually emitted more $\mathrm{NH}_{3}$ after drying for six days (i.e. compare the $\mathrm{NH}_{3}$ emission factors from the 5 and 11 November Block A burns in Table 3). Certainly, much greater fuel changes could occur in several months than in one week and it is also possible that the rainfall noted by Hegg et al. (1988) constituted a deposition event. An important point is that given the very large number of environmental variables that could impact fire emissions it can be very difficult to isolate the impact of any one variable on the emissions from real fires.

The $\mathrm{EF}\left(\mathrm{PM}_{2.5}\right)$ values of Hardy et al. (1996) lie close to our best fit line (Fig. 2) and they observed an average $\mathrm{EF}\left(\mathrm{PM}_{2.5}\right.$ ) of $9.0 \pm 1.6 \mathrm{~g} \mathrm{~kg}^{-1}$ (at an average MCE of 0.925 ), which is similar to our study-average $\mathrm{EF}\left(\mathrm{PM}_{2.5}\right)$ for the southwestern burns of $7.67 \pm 1.27 \mathrm{~g} \mathrm{~kg}^{-1}$. In contrast, the average $\mathrm{EF}\left(\mathrm{PM}_{3.5}\right)$ of Radke et al. (1991) was much higher at $15.9 \mathrm{~g} \mathrm{~kg}^{-1}$ despite a higher average MCE of 0.946 (Fig. 2). This value is much higher than our observed $\mathrm{EF}\left(\mathrm{PM}_{2.5}\right)$ although the Radke observed large intrafire variability for the Lodi 2 fire $\left(\mathrm{EF}=23.0 \pm 19.6 \mathrm{~g} \mathrm{~kg}^{-1}\right)$. 


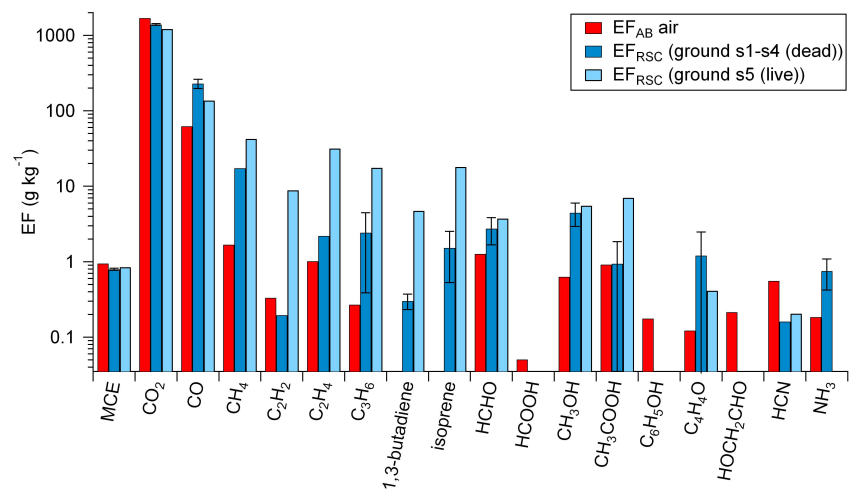

Fig. 3. Emission factors $\left(\mathrm{g} \mathrm{kg}^{-1}\right)$ as measured from both the airborne and ground-based FTIR for the ME burn of Camp Lejeune, 1 March 2010. $\mathrm{AB}=$ airborne, $\mathrm{RSC}=$ ground-based sampling.

\subsection{Coupled airborne and ground-based measurements}

For the Holly Shelter and ME prescribed fires we sampled both the lofted emissions with the Twin Otter aircraft and the unlofted emissions with our ground-based FTIR system. The ground-based ME samples were from smoldering and weakly-flaming combustion of stumps, while those at the Holly Shelter site were of smoldering and weakly-flaming litter and shrubs. When present the flame lengths for the sampled combustion were only $\sim 5-8 \mathrm{~cm}$ and too small to create a convection column. In both cases the combustion sampled from the ground was dominated overall by smoldering and contributed to a dense, ground-level layer of smoke. We therefore classify this as residual smoldering combustion following Bertschi et al. (2003).

The ground-based measurements of RSC emissions from the ME site are shown in Table 5 and Fig. 3. Figure 3 shows a comparison of the emission factors from the airborne FTIR and the ground-based samples, with the dead stump samples (samples 1-4) averaged together and the sample from the base of the living tree (sample 5) as a separate data series. These stump samples were nearly pure smoldering, with lower MCEs than the smoke sampled from the airborne platform. The nitrogen-containing emissions associated with flaming combustion, namely $\mathrm{NO}, \mathrm{NO}_{2}$ and $\mathrm{HONO}$, were not detected in the ground-based samples, while gas-phase $\mathrm{NH}_{3}$ and $\mathrm{HCN}$ which are nitrogen-containing emissions that can be produced by smoldering were observed in these samples. The sample-to-sample variability in emission factors among the dead stump samples was fairly low for each species measured. With the exception of $\mathrm{C}_{2} \mathrm{H}_{2}$, which can be a product of both flaming and smoldering combustion, the ground-based RSC EF for the other hydrocarbon species were $\sim 1.5$ to 65 times higher than the airborne EF. A similar trend is observed for the oxygenated volatile organic species (OVOC), with higher emissions from the RSC samples than the airborne. Two species clearly detected in the ground-based emissions

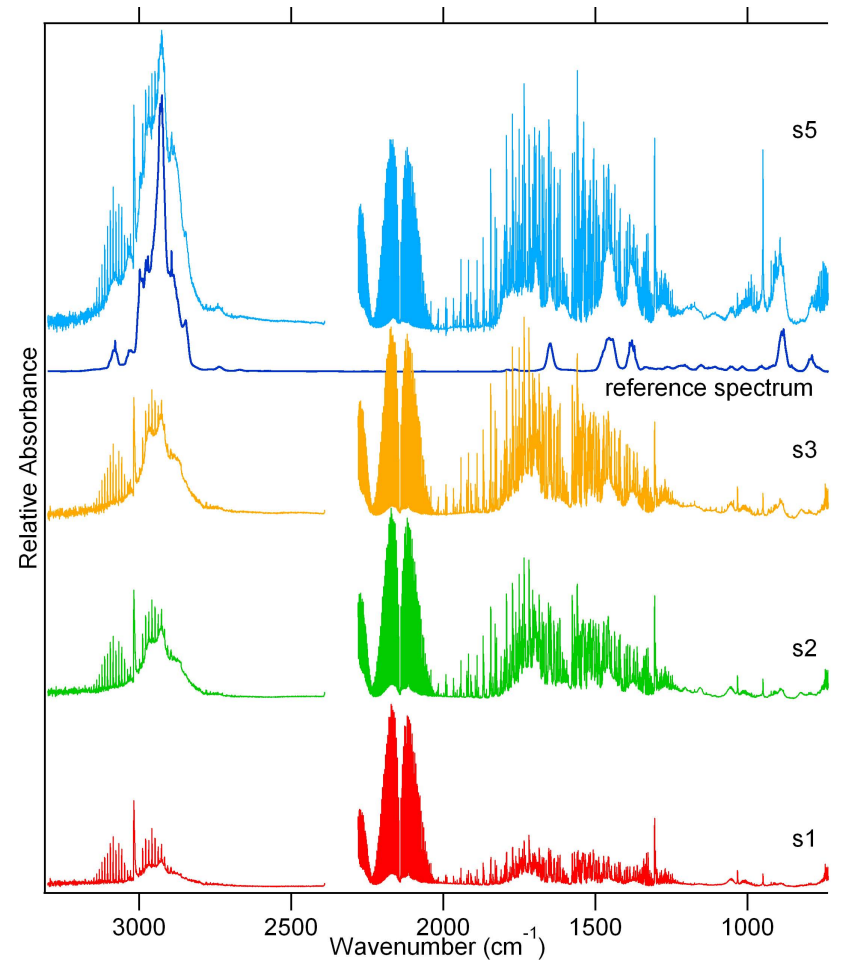

Fig. 4. Absorption spectra of ground samples normalized to the $\mathrm{CO}$ absorption band centered at $2143 \mathrm{~cm}^{-1}$. Samples s1-s3 are of smoldering emissions from dead stumps while sample s5 is combustion occurring at the base of a living tree. The reference spectrum is a linear sum of three equal parts of the monoterpene species, $\alpha$ pinene, $\beta$-pinene, and D-limonene spectra (Sharpe et al., 2004) and is shown only as a qualitative comparison.

that were not observed in the airborne samples were the unsaturated hydrocarbons 1,3-butadiene and isoprene.

The sample of smoke from the smoldering base of a damaged, live tree was characterized by much higher hydrocarbon emissions than the dead stump samples, including very high isoprene and 1,3-butadiene emissions even though it burned with the highest MCE of samples at this site. Isoprene is emitted from plants and can increase as a biological response to thermal or other stress (Sharkey et al., 2008). Isoprene is also a product of the combustion of many biomass fuels (Christian et al., 2003; Yokelson et al., 2008). In the samples characterized by detectable isoprene or 1,3butadiene, there were also several very large unidentified spectral features characteristic of monoterpene infrared absorption. Figure 4 shows spectra of RSC for stump samples 1-3 and 5 (the live tree). These spectra have all been normalized to the $\mathrm{CO}$ absorbance band centered at $2143 \mathrm{~cm}^{-1}$. All the sharp, narrow features in these spectra have been identified. We first call attention to the $\mathrm{C}-\mathrm{H}$ stretch region between 2700 and $3100 \mathrm{~cm}^{-1}$ where all molecules with a $\mathrm{C}-\mathrm{H}$ bond absorb. $\mathrm{C} 1$ and $\mathrm{C} 2$ hydrocarbons have resolved rotational lines while C3 and larger NMHCs or OVOCs 
Table 5. Ground-based MCE and emission factors $\left(\mathrm{g} \mathrm{kg}^{-1}\right)$.

\begin{tabular}{|c|c|c|c|c|c|c|c|c|c|c|}
\hline Date & 1 Mar 2010 & 1 Mar 2010 & 1 Mar 2010 & 1 Mar 2010 & 1 Mar 2010 & 5 Mar 2010 & 5 Mar 2010 & 5 Mar 2010 & 5 Mar 2010 & 5 Mar 2010 \\
\hline Sample \# & Sample 1 & Sample 2 & Sample 3 & Sample 4 & Sample 5 & Sample 1 & Sample 2 & Sample 3 & Sample 4 & Sample 5 \\
\hline \# samples & 4 & 4 & 1 & 1 & 2 & 3 & 1 & 2 & 2 & 1 \\
\hline \multirow[t]{2}{*}{ Location } & CL - & CL - & $\mathrm{CL}-$ & CL - & CL - & Holly & Holly & Holly & Holly & Holly \\
\hline & Unit ME & Unit ME & Unit ME & Unit ME & Unit ME & Shelter & Shelter & Shelter & Shelter & Shelter \\
\hline Description & $\begin{array}{l}\text { Dead } \\
\text { stump }\end{array}$ & $\begin{array}{l}\text { Dead } \\
\text { stump }\end{array}$ & $\begin{array}{l}\text { Dead } \\
\text { stump }\end{array}$ & $\begin{array}{l}\text { Dead } \\
\text { stump }\end{array}$ & $\begin{array}{l}\text { Base of } \\
\text { living tree }\end{array}$ & $\begin{array}{l}\text { Pine } \\
\text { litter }\end{array}$ & $\begin{array}{l}\text { Pine } \\
\text { litter }\end{array}$ & $\begin{array}{l}\text { Understory } \\
\text { shrubs }\end{array}$ & $\begin{array}{l}\text { Understory } \\
\text { shrubs }\end{array}$ & $\begin{array}{c}\text { Understory } \\
\text { shrubs }\end{array}$ \\
\hline MCE & 0.759 & 0.796 & 0.823 & 0.800 & 0.850 & 0.931 & 0.864 & 0.914 & 0.849 & 0.794 \\
\hline $\mathrm{CO}_{2}$ & 1340 & 1394 & 1421 & 1422 & 1218 & 1686 & 1567 & 1660 & 1544 & 1446 \\
\hline $\mathrm{CO}$ & 271 & 227 & 195 & 226 & 137 & 80 & 156 & 100 & 175 & 238 \\
\hline $\mathrm{CH}_{4}$ & 15.95 & 19.56 & 18.67 & 15.37 & 42.47 & 2.07 & 2.24 & 1.70 & 2.89 & 2.20 \\
\hline $\mathrm{C}_{2} \mathrm{H}_{2}$ & 0.12 & 0.21 & 0.26 & & 8.86 & 0.38 & 0.20 & 0.42 & 0.08 & 0.06 \\
\hline $\mathrm{C}_{2} \mathrm{H}_{4}$ & 1.63 & 1.30 & 3.57 & 2.29 & 31.74 & 1.56 & 1.43 & 1.41 & 0.72 & 0.49 \\
\hline $\mathrm{C}_{3} \mathrm{H}_{6}$ & 1.40 & 2.34 & 3.54 & & 17.57 & 0.50 & 0.71 & 0.37 & 0.45 & 0.24 \\
\hline 1,3-butadiene & 0.18 & 0.35 & 0.37 & & 4.72 & 0.07 & 0.13 & 0.08 & & \\
\hline isoprene & 0.28 & 1.09 & 3.21 & & 18.02 & 0.11 & 0.18 & 0.11 & 0.06 & 0.01 \\
\hline НCHO & 2.06 & 2.40 & 3.77 & & 3.74 & 1.72 & 1.33 & 1.33 & 0.38 & 1.03 \\
\hline \multirow{2}{*}{\multicolumn{11}{|c|}{$\mathrm{HCOOH}$}} \\
\hline & & & & & & & & & & \\
\hline $\mathrm{CH}_{3} \mathrm{COOH}$ & 0.72 & 0.50 & 1.60 & & 7.05 & 1.26 & 1.36 & 0.52 & & 0.24 \\
\hline \multicolumn{11}{|l|}{$\mathrm{C}_{6} \mathrm{H}_{5} \mathrm{OH}$} \\
\hline $\mathrm{C}_{4} \mathrm{H}_{4} \mathrm{O}$ & 1.00 & 1.03 & 1.59 & & 0.41 & 0.15 & 0.22 & 0.09 & 0.11 & 0.27 \\
\hline $\mathrm{HCN}$ & 0.10 & 0.30 & 0.08 & & 0.20 & 0.65 & 0.47 & 0.43 & 0.81 & 0.31 \\
\hline $\mathrm{NH}_{3}$ & & 0.23 & 0.58 & 1.45 & & 0.03 & 0.14 & 0.02 & 1.18 & 0.11 \\
\hline
\end{tabular}

typically tend to have broad continuum absorptions peaking near $2965 \mathrm{~cm}^{-1}$. Our RSC spectra show a continuum maximizing near $2930 \mathrm{~cm}^{-1}$, which is characteristic of monoterpene species such as limonene and $\alpha$ - and $\beta$-pinene. The monoterpene-like feature is highest for the emissions from the living tree base, which also had the highest isoprene and hydrocarbon emissions. The feature at $\sim 900 \mathrm{~cm}^{-1}$, which is characteristic of isoprene and 1,3-butadiene absorption, cannot be fully explained by absorption of these two species alone. As suggested by Fig. 4, it appears that monoterpenes are also absorbing in this region. In this figure we have generated a synthetic reference spectrum that is $33 \%$ each of $\alpha$ pinene, $\beta$-pinene and $\mathrm{D}$-limonene. The synthetic spectrum nicely matches the "residual" non-structured absorption of the four spectra, especially S5, smoke from the live tree.

Monoterpenes are present in significant levels in the $P i$ nus genus and are a common constituent of a tree's response to injury or disease (Paine et al., 1987) and may be introduced into the gas phase (distilled) by the heat from a fire. It is possible that incomplete combustion or pyrolysis of these monoterpenes accounts for some of the extremely high emissions of lower molecular mass hydrocarbons from the burning live tree. It is also possible that the live sample was actually what is known as "fatwood", which is wood that is naturally impregnated with terpene-containing resin. Regardless, all the unsaturated hydrocarbons measured in these RSC samples are highly reactive and could lead to ozone and SOA formation (Alvarado and Prinn, 2009).

We explore the potential impact of the emissions sampled from the ground on the total emissions from the fires in our study. The total fire emission factor, $\mathrm{EF}_{\mathrm{TOT}}$, for any emitted species will be a combination of $\mathrm{EF}$ from both the lofted and the RSC emissions according to the following (Bertschi et al., 2003):

$\mathrm{EF}_{\mathrm{TOT}}=\mathrm{EF}_{\mathrm{RSC}} \times \mathrm{F}_{\mathrm{RSC}}+\mathrm{EF}_{\mathrm{AB}} \times \mathrm{F}_{\mathrm{AB}}$

where $\mathrm{EF}_{\mathrm{RSC}}$ and $\mathrm{EF}_{\mathrm{AB}}$ are the emission factors from RSC and lofted (airborne) emissions, respectively. $F_{\mathrm{RSC}}$ and $F_{\mathrm{AB}}$ are the fractions of total fuel consumption during RSC and the fraction of total emissions that are entrained in the lofted plume, respectively.

The strategies adopted by land managers for prescribed burning are designed to minimize both the amount of RSC and its impact on local populations (Hardy et al., 2001). So although the RSC emission factors may be high $\left(\mathrm{EF}_{\mathrm{RSC}}\right.$ of Eq. 3), the fraction of fuel consumption by RSC ( $F_{\mathrm{RSC}}$ of Eq. 3) is usually small for most prescribed fires. This fraction is uncertain however and is the subject of future measurements. For now, adopting a modest $\mathrm{F}_{\mathrm{RSC}}$ estimate of $5 \%$ for prescribed fires, we estimate the impact that including RSC has on the fire-average emission factors for our Camp Lejeune ME burn. Setting $\mathrm{F}_{\mathrm{RSC}}$ and $\mathrm{F}_{\mathrm{AB}}$ to $5 \%$ and $95 \%$, respectively, and taking $\mathrm{EF}_{\mathrm{RSC}}$ from the average of the dead stump samples only, the following species showed significant increases: $\mathrm{CO}\left(\mathrm{EF}_{\mathrm{AB}}=62.6, \mathrm{EF}_{\mathrm{TOT}}=70.9 \mathrm{~g} \mathrm{~kg}^{-1}\right)$, $\mathrm{CH}_{4} \quad\left(\mathrm{EF}_{\mathrm{AB}}=1.69, \quad \mathrm{EF}_{\mathrm{TOT}}=2.47 \mathrm{~g} \mathrm{~kg}^{-1}\right), \quad \mathrm{C}_{3} \mathrm{H}_{6}$ $\left(\mathrm{EF}_{\mathrm{AB}}=0.27, \quad \mathrm{EF}_{\mathrm{TOT}}=0.38 \mathrm{~g} \mathrm{~kg}^{-1}\right), \quad \mathrm{CH}_{3} \mathrm{OH}$ $\left(\mathrm{EF}_{\mathrm{AB}}=0.63, \quad \mathrm{EF}_{\mathrm{TOT}}=0.82 \mathrm{~g} \mathrm{~kg}^{-1}\right)$, furan $\left(\mathrm{EF}_{\mathrm{AB}}=0.12\right.$, $\left.\mathrm{EF}_{\mathrm{TOT}}=0.18 \mathrm{~g} \mathrm{~kg}^{-1}\right)$. With just a $5 \%$ contribution from RSC to the total emissions, the emission factors of several species increase by up to $32 \%$ for those species measured in both the ground and airborne platforms for this fire. The 
effect we have calculated does not consider the emissions from the smoldering, damaged live tree because we do not have information to estimate the relative weight this sample should have in calculating $\mathrm{EF}_{\mathrm{RSC}}$. Since most of these emission factors are even higher from this sample, the contribution of RSC to $\mathrm{EF}_{\mathrm{TOT}}$ would be even greater when including these measurements.

Due to the hazards associated with fire sampling, the $\mathrm{F}_{\mathrm{AB}}$ and $\mathrm{F}_{\mathrm{RSC}}$ are difficult to determine. In contrast to the minimal amount of RSC assumed for prescribed fires, wildfires normally burn when "fire danger" is at high levels and moisture content of dead forest floor and coarse woody fuels moisture is at a minimum (Deeming et al., 1978). More, larger diameter fuels are consumed when their fuel moisture is low which may influence the amount of RSC. Based on the emission factors as measured from the air and ground for the ME fire, the flaming compounds that were measured in the airborne smoke but were not measured from the ground (e.g. $\mathrm{NO}_{\mathrm{x}}, \mathrm{HONO}$ ) would be overestimated by up to a factor dependent on $\mathrm{F}_{\mathrm{RSC}}$ if only airborne sampling was performed. On the other hand, as seen in Fig. 3, those smoldering compounds with significant RSC emissions would be underestimated (e.g. $\mathrm{CO}, \mathrm{CH}_{4}, \mathrm{C}_{2} \mathrm{H}_{4}, \mathrm{CH}_{3} \mathrm{OH}$ ) or not predicted at all (1,3-butadiene, isoprene) if ground-based measurements of RSC were not considered. This case only considers the burning of the understory and RSC from the ME fire. Wildfires often can burn canopy fuels (crown fires) and can also result in different emissions (Cofer et al., 1998) than understory burns due to the intense nature of a crown fire.

The Holly Shelter ground samples represented burning pine litter and shrubs. The NC winter of 2010 had high rainfall, and so high fuel moisture likely explains why emissions from these fuels contributed to RSC at this site rather than mostly flaming combustion as is typically the case for litter and foliage. Under conditions closer to the long-term average, or allowing time for the fuels to dry, consumption of the shrubs and at least the surface of the litter layer would likely have contributed to the lofted emissions, although it should be noted that the conditions for this fire were adequate for the fuel management goals. Although the average MCE of the ground samples at this site was lower than the average MCE of the airborne samples, the ground-based emission factors are actually fairly similar to the airborne emission factors. The emission factors from all the Holly Shelter airborne and ground-based samples are relatively similar for each species across a wide range of MCE with the exception of Sample 4. Sample 4 had the highest $\mathrm{EF}(\mathrm{HCN})$ and $\mathrm{EF}\left(\mathrm{NH}_{3}\right)$ (nearly ten times the next highest) but also the lowest $\mathrm{EF}(\mathrm{HCHO})$, nearly a factor of three lower than the next lowest sample. These emissions had much lower $\mathrm{EF}$ values for $\mathrm{CH}_{4}$ and many other species than from the RSC at the Camp Lejeune location.

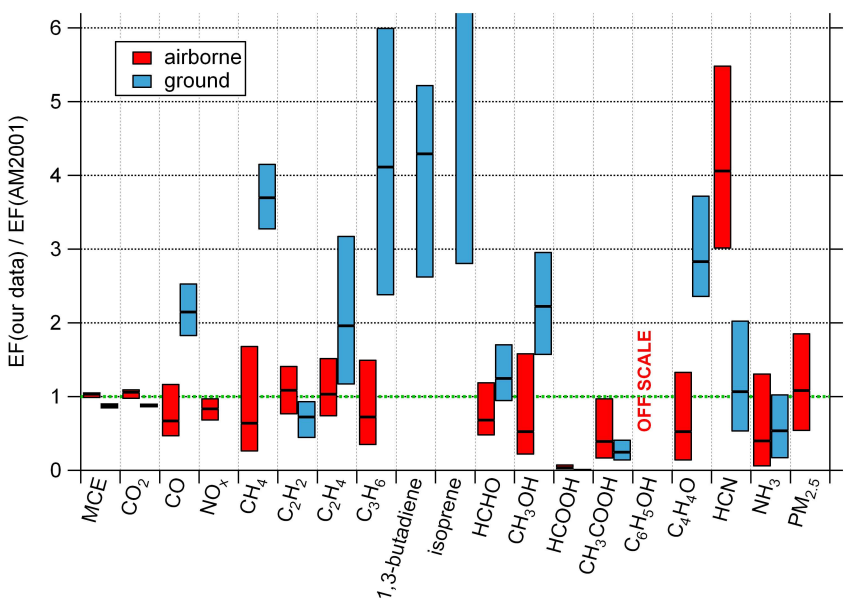

Fig. 5. Comparison of our airborne and ground-based emission factors with the recommendations of Andreae and Merlet (2001) (AM2001). For our data, the upper and lower bounds of the bars represent the range of our data, while the line inside the bar represents the average EF.

\subsection{Comparison of emission factors with compiled reference data for extratropical forests}

The emission factors from this study are also being incorporated into an up-to-date compilation of global biomass burning emission factors (Akagi et al., 2011b). In addition to the Akagi et al. (2011b) emission factor compilation there are also compilations by Urbanski et al. (2009b) and Andreae and Merlet (2001). We briefly compare our results with a previous emission factor compilation by Andreae and Merlet, (2001) (herein referred to as AM2001), which is widely used in models. We compare the average of our temperate conifer forest understory fires, as well as our ground-based emission factors from the ME fire to the extratropical forest data of AM2001. The ground-based data only include the dead stump samples. Figure 5 shows the ratio of our emission factors to those of AM2001 for those species reported in both. For the ratios we used the range of our emission factors (represented by the upper and lower bounds of the bars) as well as the average EF. Since our EF were dependent on MCE, this should partially compensate for any differences due to different MCE. We sampled six temperate conifer forest fires of high MCE (0.942-0.957) and only two of lower MCE (0.885-0.913), thus our average values of Fig. 5 favor the lower values of the range for the smoldering compounds for the airborne measurements.

From the figure, for most species the range of our airborne results is consistent with the EF values of AM2001, although average values are typically lower than AM2001 possibly due to the MCE effects discussed previously. Some notable exceptions are $\mathrm{HCOOH}$, phenol and HCN. Our average airborne $\mathrm{EF}(\mathrm{HCOOH})$ is roughly 30 times lower than AM2001, although it should be noted that about a factor of 
two can be attributed to the fact that much of the data used in AM2001 was based on the now outdated $\mathrm{HCOOH}$ spectral parameters (see Sect. 3.1). The airborne $\mathrm{EF}$ (phenol) ranges from 14 to 220 times higher (off-scale on Fig. 5) than that for AM2001. Phenol is potentially important as a precursor to SOA formation through aqueous-phase processing (Sun et al., 2010). Similarly our $\mathrm{EF}(\mathrm{HCN})$ is 3 to 5.5 times higher than AM2001.

On the other hand, for the ground-based samples our emission factors are much higher than AM2001 for the smoldering compounds, with the exception of $\mathrm{CH}_{3} \mathrm{COOH}(\sim 3$ times lower than $\mathrm{AM} 2001)$ and $\mathrm{NH}_{3}$. This is important as researchers who may be modeling the impacts of smoke from residual smoldering combustion would be underestimating most of the emissions without specific RSC emission inventories.

\subsection{Preliminary comparison of field and laboratory results}

A separate paper will present a detailed comparison and synthesis of the results from the laboratory and field work of this project. Here we briefly summarize some of the main differences. Two chemical species were observed in the laboratory fires that burned fuels collected from the sites of the prescribed fires sampled in this work (Burling et al., 2010), but were not observed in the actual prescribed fires. Gas-phase sulfur dioxide $\left(\mathrm{SO}_{2}\right)$ and hydrochloric acid $(\mathrm{HCl})$ were observed during flaming combustion in the laboratory fires, but were below the detection limits for the airborne field measurements. Based on the typical $\Delta \mathrm{SO}_{2} / \Delta \mathrm{CO}_{2}$ emission ratios observed in the laboratory experiments (e.g. Fig. 2 of Burling et al., 2010) and the $\Delta \mathrm{CO}_{2}$ measured in our airborne experiments, $\mathrm{SO}_{2}$ is expected to be below the detection limit in the airborne samples due to the lower smoke concentrations. Based on the same reasoning, extending the $\Delta \mathrm{HCl} / \Delta \mathrm{CO}_{2}$ emission ratios observed in the lab to the measured airborne $\mathrm{CO}_{2}$ should yield detectable $\mathrm{HCl}$ concentrations. $\mathrm{HCl}$ is well known as a "sticky" gas readily adhering to system surfaces (Johnson et al., 2003; Komazaki et al., 2002; Webster et al., 1994). While our inlet was coated with a halocarbon wax to minimize surface losses the lack of $\mathrm{HCl}$ detection was likely due to sampling losses on our airborne and ground-based (inlet) systems, whereas the laboratory system of Burling et al. (2010) utilized an open path spectrometer.

Gas-phase nitrous acid (HONO) is an important source of the hydroxyl radical $(\mathrm{OH})$ and affects the photochemistry of aging plumes (Alvarado and Prinn, 2009; Trentmann et al., 2005). HONO was observed from the air in all fires with the exception of the Bear Pen and Holly Shelter fires in NC (the two fires with limited sampling) confirming recent observations with similar fuels in the laboratory fires of Burling et al. (2010) and Veres et al. (2010). HONO was below the detection limit in the ground-based

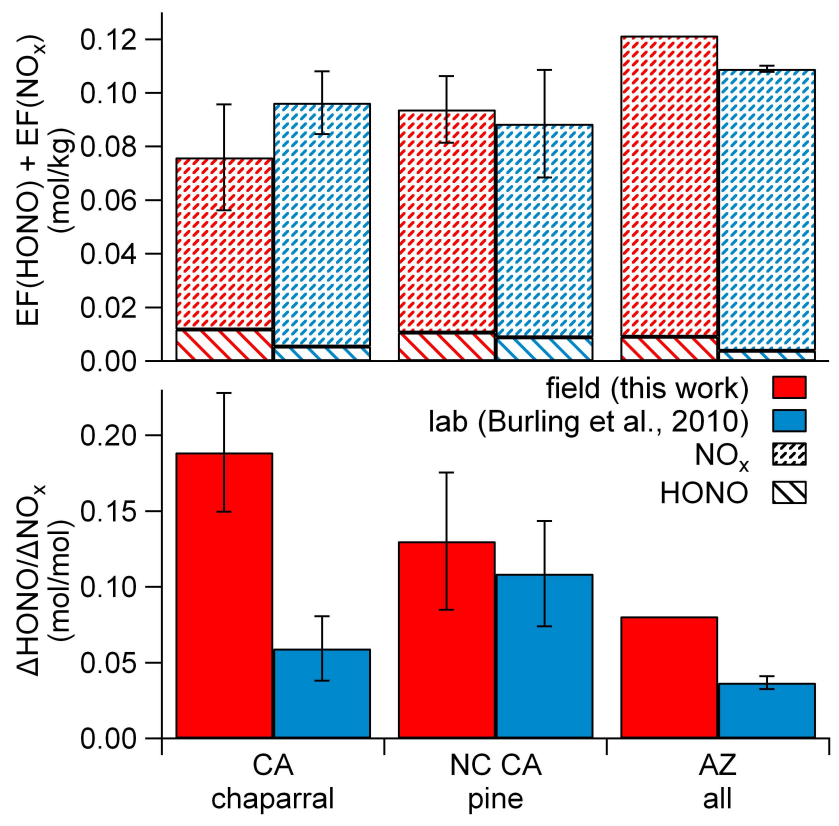

Fig. 6. Lower panel: comparison of the average molar $\Delta \mathrm{HONO} / \Delta \mathrm{NO}_{\mathrm{x}}$ ratios for the various fuel types studied in this work (airborne) and the laboratory study of Burling et al. (2010). Upper panel: average sum of the molar emission factors of HONO and $\mathrm{NO}_{\mathrm{x}}$ (in mol kg-1).

samples. The $\Delta \mathrm{HONO} / \Delta \mathrm{NO}_{\mathrm{x}}\left(\mathrm{ppb} \mathrm{ppb}^{-1}\right.$ or $\left.\mathrm{mol} \mathrm{mol}^{-1}\right)$ ratios ranged from 0.077 to 0.22 for the fires sampled from the air. Although HONO has been observed as a product of flaming combustion (Burling et al., 2010), and we observed a positive correlation between $\mathrm{EF}(\mathrm{HONO})$ and MCE, $\mathrm{EF}(\mathrm{HONO})$ is also dependent on the nitrogen-content of the fuels, which while known in the Burling et al. (2010) laboratory study, is unknown for the present field experiments. In Fig. 6 we compare the $\Delta \mathrm{HONO} / \Delta \mathrm{NO}_{\mathrm{x}}$ from the laboratory study of Burling et al. (2010) to the airborne samples in this work. We group these fires according to location and fuel type. Comparing the field $\Delta \mathrm{HONO} / \Delta \mathrm{NO}_{\mathrm{x}}$ emission ratios with those from the laboratory experiments of Burling et al. (2010) (lower panel of Fig. 6) we obtain: conifer forest understory $(0.130 \pm 0.045(1 \sigma)$ airborne, $0.109 \pm 0.039$ lab); oak woodland (0.0806 airborne, $0.036 \pm 0.008 \mathrm{lab})$; chaparral $(0.189 \pm 0.039$ airborne, $0.064 \pm 0.034 \mathrm{lab})$. Thus, our field $\Delta \mathrm{HONO} / \Delta \mathrm{NO}_{\mathrm{x}}$ values are systematically higher than the lab values of Burling et al. (2010) although the enhancement is not statistically significant for the conifer forest understory fires. The upper panel of Fig. 6 shows the sum of the molar EF for $\mathrm{NO}_{\mathrm{x}}$ (as $\mathrm{NO}$ ) and $\mathrm{HONO}$, in $\mathrm{mol} \mathrm{kg}^{-1}$ and their relative contributions to the sum for the same fuel types. Compared to the lab data in Burling et al. (2010), we observed higher values for molar $\mathrm{EF}(\mathrm{HONO})$ and lower values for molar $\mathrm{EF}\left(\mathrm{NO}_{\mathrm{x}}\right.$ as $\left.\mathrm{NO}\right)$ yet the sums of these two are similar between the respective laboratory and field fires. These 
differences may be due to HONO formation via heterogeneous reaction of $\mathrm{NO}_{\mathrm{x}}$ on smoke particles early in the plume before photolysis, leading to higher $\mathrm{HONO}$ (and lower $\mathrm{NO}_{\mathrm{x}}$ ) in the airborne samples. The laboratory samples of Burling et al. (2010) were a few seconds old while the airborne samples considered in this work were in all cases several minutes old. However, the particle and water concentrations were often higher and the skies often more overcast for the conifer forest understory burns so the differences in these ratios may instead reflect subtle differences in fuel type or burning conditions. Regardless of the lab/field differences, both the laboratory and field experiments clearly confirm that HONO is a major oxidant source in biomass burning plumes.

\section{Conclusions}

We have measured and compiled emission factors for 14 prescribed fires in temperate ecosystems of the southeastern and southwestern US. The emission factors as a function of MCE of known smoldering trace gases for the conifer forest understory fires of CA and NC were well-represented by linear regression with $R^{2}$ ranging from $0.80-0.98$. With the exception of one fire, $\mathrm{EF}\left(\mathrm{PM}_{2.5}\right)$ were also well-represented by a straight line $\left(R^{2}=0.61\right)$. We also compared the emission factors with the limited previous field measurements of similar fuel types. In general, our results agreed well with measurements of Yokelson et al. (1999) who measured the emissions from fires of conifer forest understories in the same southeastern region. The emission factors for fires in rural pineoak fires in Mexico (Yokelson et al., 2011) were more scattered due possibly to the unregulated and less-controlled nature of the latter fires or differences in the fuel environments.

Whereas the emission factors for the conifer forest understory chemical species showed excellent correlation (or anti-correlation) with MCE, for several of the emissions from chaparral fires the EF relation with MCE was strongly influenced by the single burn at low MCE (Grant B). This was particularly true for the oxygenated species $\mathrm{HCHO}, \mathrm{HCOOH}$, $\mathrm{CH}_{3} \mathrm{COOH}$ and phenol. The emission factors of $\mathrm{CH}_{4}, \mathrm{C}_{3} \mathrm{H}_{6}$, $\mathrm{CH}_{3} \mathrm{OH}$, furan, and $\mathrm{NH}_{3}$ as a function of MCE had high correlation coefficients $(>0.76)$. Compared to the limited previous field work on the emissions from burning of chaparral fuels, our gas-phase emission factors agreed well. Our $\mathrm{EF}\left(\mathrm{PM}_{2.5}\right)$ values agreed well with Hardy et al. (1996), but were in general lower than the widely scattered $\mathrm{EF}(\mathrm{PM})$ of Radke et al. (1991).

For two fires we were able to measure the mixed flaming and smoldering emissions from the aircraft in the smoke plume above the fire while also measuring the emissions at ground level that were produced by residual smoldering combustion after the flame front passed. The RSC from the Camp Lejeune ME burn consisted of high emissions of hydrocarbon and OVOC species associated with low-MCE, pure smoldering emissions. We also measured significant emissions of 1,3-butadiene and isoprene in the RSC smoke, species that were below detection limits in the lofted smoke. The RSC from the base of a live tree had very high hydrocarbon emission factors, including the highest 1,3-butadiene and isoprene of all ground-based samples. The ground-based samples from the Holly Shelter burn were probably less typical of RSC due to the low burn intensity at this site. Although these samples burned had a range of MCE values, in general, the ground-based EF were similar to the airborne EF at this site. Better estimates of the fuel consumption contributing to the different dispersion regimes will be needed to fully utilize these emissions data. We plan to explore the contribution of RSC to the total emission factor in an upcoming study in late 2011 including ground and airborne measurement of a wildfire-like high intensity prescribed fire in a pine stand in the southern US.

Gas-phase nitrous acid was measured in all fires, confirming the recent laboratory observations of HONO from burns of similar fuel types (Burling et al., 2010; Roberts et al., 2010; Veres et al., 2010). The $\Delta \mathrm{HONO} / \Delta \mathrm{NO}_{\mathrm{x}}$ ratios observed in our airborne experiment are in general higher than those measured in the laboratory study of Burling et al. (2010). On the other hand, the molar sums of HONO and $\mathrm{NO}_{\mathrm{x}}$ were similar for the laboratory study and our work suggesting possible further production of $\mathrm{HONO}$ from $\mathrm{NO}_{\mathrm{x}}$ during the several minutes from emission to measurement from the airborne platform.

Acknowledgements. This work was supported by the Strategic Environmental Research and Development Program (SERDP) Resource conservation projects RC-1648 and RC-1649 and administered through agreement Forest Service Research Joint Venture Agreement 08JV11272166039, and we thank our sponsors for their continuing support. Customization of the USFS Twin Otter was supported primarily by NSF grant ATM 0513055. R. Y. and S. A. were also supported by NSF grant ATM-0936321. Deployment to the Turtle and Shaver Fires as well as participation of Shawn Urbanski was supported partially by Joint Fire Science Program grant 08-1-6-09. Special thanks to our pilots Scott Miller and Aaron Knobloch, Twin Otter mechanic Kevin Bailey, Andrew Robillard (San Luis Jet Center), and our many able collaborators on the ground including: Jason McCarty (SBCFD), Brendan Ripley (VCFD), Dan Ardoin (VAFB), Danny Becker, Susan Cohen, Gary Curcio, Angie Carl, Drew Leiendecker (Ft. Huachuca), Joey Chong, Bonni Corcoran, Gloria Burke, Ania Wrona, Jesse Lozano.

Edited by: A. Engel

\section{References}

Achtemeier, G. L.: Measurements of moisture in smoldering smoke and implications for fog, Int. J. Wildland Fire, 15, 517-525, doi:10.1071/WF05115, 2006.

Aiken, A. C., DeCarlo, P. F., Kroll, J. H., Worsnop, D. R., Huffman, J. A., Docherty, K. S., Ulbrich, I. M., Mohr, C., Kimmel, J. R., Sueper, D., Sun, Y., Zhang, Q., Trimborn, A., Northway, 
M., Ziemann, P. J., Canagaratna, M. R., Onasch, T. B., Alfarra, M. R., Prevot, A. S. H., Dommen, J., Duplissy, J., Metzger, A., Baltensperger, U., and Jimenez, J. L.: O/C and OM/OC Ratios of Primary, Secondary, and Ambient Organic Aerosols with HighResolution Time-of-Flight Aerosol Mass Spectrometry, Environ. Sci. Technol., 42, 4478-4485, doi:10.1021/es703009q, 2008.

Akagi, S. K., Craven, J., Taylor, J., McMeeking, G. R., Yokelson, R. J., Burling, I. R., Urbanski, S., Wold, C. E., Seinfeld, J. H., Coe, H., and Alvarado, M. J.: Evolution of trace gases and particles in smoke from a chaparral fire in California, Atmos. Chem. Phys. Discuss, 11, 22483-22544, doi:10.5194/acpd-11-224832011, 2011a.

Akagi, S. K., Yokelson, R. J., Wiedinmyer, C., Alvarado, M. J., Reid, J. S., Karl, T., Crounse, J. D., and Wennberg, P. O.: Emission factors for open and domestic biomass burning for use in atmospheric models, Atmos. Chem. Phys., 11, 4039-4072, doi:10.5194/acp-11-4039-2011, 2011 b.

Alvarado, M. J. and Prinn, R. G.: Formation of ozone and growth of aerosols in young smoke plumes from biomass burning: 1. Lagrangian parcel studies, J. Geophys. Res., 114, D09306, doi:10.1029/2008JD011144, 2009.

Andreae, M. O. and Merlet, P.: Emission of trace gases and aerosols from biomass burning, Global Biogeochem. Cy., 15, 955-966, doi:10.1029/2000GB001382, 2001.

Bertschi, I., Yokelson, R. J., Ward, D. E., Babbitt, R. E., Susott, R. A., Goode, J. G., and Hao, W. M.: Trace gas and particle emissions from fires in large diameter and belowground biomass fuels, J. Geophys. Res., 108, 8472, doi:10.1029/2002JD002100, 2003.

Biswell, H.: Prescribed Burning in California Wildlands Vegetation Management University of California Press, Berkeley, CA, USA, 255 pp., 1999.

Bond, T. C., Streets, D. G., Yarber, K. F., Nelson, S. M., Woo, J.H., and Klimont, Z.: A technology-based global inventory of black and organic carbon emissions from combustion, J. Geophys. Res., 109, D14203, doi:10.1029/2003JD003697, 2004.

Brown, D. E.: The Biotic Communities of the American Southwest - United States and Mexico. Desert Plants, 4, 1-341. Reprinted and revised 1994 as Biotic Communities: Southwestern United States and Northwestern Mexico, University of Utah Press, Salt Lake City, Utah, USA, 342 pp., 1982.

Burling, I. R., Yokelson, R. J., Griffith, D. W. T., Johnson, T. J., Veres, P., Roberts, J. M., Warneke, C., Urbanski, S. P., Reardon, J., Weise, D. R., Hao, W. M., and de Gouw, J.: Laboratory measurements of trace gas emissions from biomass burning of fuel types from the southeastern and southwestern United States, Atmos. Chem. Phys., 10, 11115-11130, doi:10.5194/acp10-11115-2010, 2010.

Butkovskaya, N. I., Pouvesle, N., Kukui, A., and Le Bras, G.: Mechanism of the OH-Initiated Oxidation of Glycolaldehyde over the Temperature Range 233-296 K, J. Phys. Chem. A, 110, 13492-13499, doi:10.1021/jp064993k, 2006.

Christian, T. J., Kleiss, B., Yokelson, R. J., Holzinger, R., Crutzen, P. J., Hao, W. M., Saharjo, B. H., and Ward, D. E.: Comprehensive laboratory measurements of biomass-burning emissions: 1 . Emissions from Indonesian, African, and other fuels, J. Geophys. Res., 108, 4719, doi:10.1029/2003JD003704, 2003.

Christian, T. J., Yokelson, R. J., Carvalho, J. A., Griffith, D. W. T., Alvarado, E. C., Santos, J. C., Neto, T. G. S., Veras, C. A. G., and Hao, W. M.: The tropical forest and fire emissions experiment: Trace gases emitted by smoldering logs and dung from deforestation and pasture fires in Brazil, J. Geophys. Res., 112, D18308, doi:10.1029/2006JD008147, 2007.

Cofer, W. R., Winstead, E. L., Stocks, B. J., Goldammer, J. G., and Cahoon, D. R.: Crown fire emissions of $\mathrm{CO}_{2}, \mathrm{CO}, \mathrm{H}_{2}, \mathrm{CH}_{4}$, and TNMHC from a dense Jack pine boreal forest fire, Geophys. Res. Lett., 25, 3919-3922, doi:10.1029/1998GL900042, 1998.

Cofer, W. R., Levine, J. S., Riggan, P. J., Sebacher, D. I., Winstead, E. L., Shaw, E. F., Brass, J. A., and Ambrosia, V. G.: Trace Gas Emissions From a Mid-Latitude Prescribed Chaparral Fire, J. Geophys. Res., 93, 1653-1658, doi:10.1029/JD093iD02p01653, 1988.

Crutzen, P. J. and Andreae, M. O.: Biomass Burning in the Tropics: Impact on Atmospheric Chemistry and Biogeochemical Cycles, Science, 250, 1669-1678, doi:10.1126/science.250.4988.1669, 1990.

Deeming, J. E., Burgan, R. E., and Cohen, J. D.: The 1978 National Fire-Danger Rating System, Gen. Tech. Rep. INT-39, USDA Forest Service, Ogden, UT, 1978.

Ebeling, J. M. and Jenkins, B. M.: Physical and chemical properties of biomass fuels, Trans. ASAE, 28, 898-902, 1985.

Ferek, R. J., Reid, J. S., Hobbs, P. V., Blake, D. R., and Liousse, C.: Emission factors of hydrocarbons, halocarbons, trace gases and particles from biomass burning in Brazil, J. Geophys. Res., 103, 32107-32118, doi:10.1029/98JD00692, 1998.

Giglio, L., Descloitres, J., Justice, C. O., and Kaufman, Y. J.: An Enhanced Contextual Fire Detection Algorithm for MODIS, Remote Sens. Environ., 87, 273-282, doi:10.1016/S00344257(03)00184-6, 2003.

Giglio, L., Loboda, T., Roy, D. P., Quayle, B., and Justice, C. O.: An active-fire based burned area mapping algorithm for the MODIS sensor, Remote Sens. Environ., 113, 408-420, doi:10.1016/j.rse.2008.10.006, 2009.

Grieshop, A. P., Donahue, N. M., and Robinson, A. L.: Laboratory investigation of photochemical oxidation of organic aerosol from wood fires 2: analysis of aerosol mass spectrometer data, Atmos. Chem. Phys., 9, 2227-2240, doi:10.5194/acp-9-2227-2009, 2009.

Griffith, D. W. T.: Synthetic Calibration and Quantitative Analysis of Gas-Phase FT-IR Spectra, Appl. Spectrosc., 50, 59-70, 1996.

Hardy, C. C., Conard, S. G., Regelbrugge, J. C., and Teesdale, D. R.: Smoke emissions from prescribed burning of southern California chaparral, USDA Forest Service, Portland, OR, Research Paper PNW-RP-486, 37 pp., 1996.

Hardy, C. C., Ottmar, R. D., Peterson, J. L., Core, J. E., and Seamon, P.: Smoke management guide for prescribed and wildland fire: 2001 edition, National Wildfire Coordination Group, Boise, ID, available online at: http://www.treesearch.fs.fed.us/pubs/5388, last access: May 2011, 2001.

Hegg, D. A., Radke, L. F., Hobbs, P. V., and Riggan, P. J.: Ammonia emissions from biomass burning, Geophys. Res. Lett., 15, 335337, doi:10.1029/GL015i004p00335, 1988.

Hegg, D. A., Radke, L. F., Hobbs, P. V., Brock, C. A., and Riggan, P. J.: Nitrogen and sulfur emissions from the burning of forest products near large urban areas, J. Geophys. Res., 92, 1470114709, 1987.

Hennigan, C. J., Sullivan, A. P., Fountoukis, C. I., Nenes, A., Hecobian, A., Vargas, O., Peltier, R. E., Case Hanks, A. T., Huey, L. 
G., Lefer, B. L., Russell, A. G., and Weber, R. J.: On the volatility and production mechanisms of newly formed nitrate and water soluble organic aerosol in Mexico City, Atmos. Chem. Phys., 8, 3761-3768, doi:10.5194/acp-8-3761-2008, 2008.

Hosseini, S., Li, Q., Cocker, D., Weise, D., Miller, A., Shrivastava, M., Miller, J. W., Mahalingam, S., Princevac, M., and Jung, H.: Particle size distributions from laboratory-scale biomass fires using fast response instruments, Atmos. Chem. Phys., 10, 80658076, doi:10.5194/acp-10-8065-2010, 2010.

Johnson, T. J., Masiello, T., and Sharpe, S. W.: The quantitative infrared and NIR spectrum of $\mathrm{CH}_{2} \mathrm{I}_{2}$ vapor: vibrational assignments and potential for atmospheric monitoring, Atmos. Chem. Phys., 6, 2581-2591, doi:10.5194/acp-6-2581-2006, 2006.

Johnson, T. J., Disselkamp, R. S., Su, Y.-F., Fellows, R. J., Alexander, M. L., and Driver, C. J.: Gas-Phase Hydrolysis of $\mathrm{SOCl}_{2}$ at 297 and 309 K: Implications for Its Atmospheric Fate, J. Phys. Chem. A, 107, 6183-6190, doi:10.1021/jp022090v, 2003.

Johnson, T. J., Profeta, L. T. M., Sams, R. L., Griffith, D. W. T. and Yokelson, R. L.: An infrared spectral database for detection of gases emitted by biomass burning, Vib. Spectrosc., 53, 97-102, doi:10.1016/j.vibspec.2010.02.010, 2010.

Keeley, J. E., Aplet, G. H., Christensen, N. L., Conard, S. G., Johnson, E. A., Omi, P. N., Peterson, D. L. and Swetnam, T. W.: Ecological foundations for fire management in North American forest and shrubland ecosystems, Gen. Tech. Rep. PNW-GTR-779, US Department of Agriculture, Forest Service, Pacific Northwest Research Station, Portland, OR, USA, available online at: http://www.treesearch.fs.fed.us/pubs/32483, 2009.

Komazaki, Y., Hashimoto, S., Inoue, T., and Tanaka, S.: Direct collection of $\mathrm{HNO}_{3}$ and $\mathrm{HCl}$ by a diffusion scrubber without inlet tubes, Atmos. Environ., 36, 1241-1246, doi:10.1016/S13522310(01)00571-4, 2002.

Mason, S. A., Field, R. J., Yokelson, R. J., Kochivar, M. A., Tinsley, M. R., Ward, D. E., and Hao, W. M.: Complex effects arising in smoke plume simulations due to inclusion of direct emissions of oxygenated organic species from biomass combustion, J. Geophys. Res., 106, 12527-12539, doi:10.1029/2001JD900003, 2001.

Naeher, L. P., Achtemeier, G. L., Glitzenstein, J. S., Streng, D. R., and Macintosh, D.: Real-time and time-integrated $\mathrm{PM}_{2.5}$ and $\mathrm{CO}$ from prescribed burns in chipped and non-chipped plots: firefighter and community exposure and health implications, J. Expos. Sci. Environ. Epidemiol., 16, 351-361, doi:10.1038/sj.jes.7500497, 2006.

Nance, J. D., Hobbs, P. V., Radke, L. F., and Ward, D. E.: Airborne measurements of gases and particles from an Alaskan wildfire, J. Geophys. Res., 98, 14873-14882, doi:10.1029/93JD01196, 1993.

Nelson Jr., R. M.: An evaluation of the carbon balance technique for estimating emission factors and fuel consumption, Research Paper SE-231, United States Department of Agriculture, Forest Service, Southeastern Forest Experiment Station, Asheville, NC, USA, 1982.

NIFC: Geographic Area Coordination Center (GACC) Website Template, National Interagency Fire Center [online] Available from: http://www.predictiveservices.nifc.gov/intelligence/2007 statssumm/2007Stats\&Summ.html last access: 26 May 2011, 2011.

Paine, T. D., Blanche, C. A., Nebeker, T. E., and Stephen, F.
M.: Composition of loblolly pine resin defenses: comparison of monoterpenes from induced lesion and sapwood resin, Can. J. For. Res., 17, 1202-1206, doi:10.1139/x87-185, 1987.

Perri, M. J., Seitzinger, S., and Turpin, B. J.: Secondary organic aerosol production from aqueous photooxidation of glycolaldehyde: Laboratory experiments, Atmos. Environ., 43, 1487-1497, doi:10.1016/j.atmosenv.2008.11.037, 2009.

Perrin, A. and Vander Auwera, J.: An improved database for the $9 \mu \mathrm{m}$ region of the formic acid spectrum, J. Quant. Spectrosc. Radiat. Transfer, 108, 363-370, doi:10.1016/j.jqsrt.2007.05.002, 2007.

Radke, L. F., Hegg, D. A., Hobbs, P. V., Nance, J. D., Lyons, J. H., Laursen, K. K., Weiss, R. E., Riggan, P. J. and Ward, D. E.: Particulate and trace gas emissions from large biomass fires in North America, in Global Biomass Burning: Atmospheric, Climatic, and Biospheric Implications, edited by: Levine, J. S., MIT Press, Cambridge, MA, USA, 209-224, 1991.

Reid, J. S., Koppmann, R., Eck, T. F. and Eleuterio, D. P.: A review of biomass burning emissions part II: intensive physical properties of biomass burning particles, Atmos. Chem. Phys., 5, 799825, doi:10.5194/acp-5-799-2005, 2005.

Rein, G., Cohen, S., and Simeoni, A.: Carbon emissions from smouldering peat in shallow and strong fronts, Proc. Comb. Inst., 32, 2489-2496, doi:10.1016/j.proci.2008.07.008, 2009.

Roberts, J. M., Veres, P., Warneke, C., Neuman, J. A., Washenfelder, R. A., Brown, S. S., Baasandorj, M., Burkholder, J. B., Burling, I. R., Johnson, T. J., Yokelson, R. J., and de Gouw, J. Measurement of HONO, HNCO, and other inorganic acids by negative-ion proton-transfer chemical-ionization mass spectrometry (NI-PT-CIMS): application to biomass burning emissions, Atmos. Meas. Tech., 3, 981-990, doi:10.5194/amt-3-981-2010, 2010.

Rothman, L. S., Gordon, I. E., Barbe, A., Benner, D. C., Bernath, P. F., Birk, M., Boudon, V., Brown, L. R., Campargue, A., Champion, J. P., Chance, K., Coudert, L. H., Dana, V., Devi, V. M., Fally, S., Flaud, J. M., Gamache, R. R., Goldman, A., Jacquemart, D., Kleiner, I., Lacome, N., Lafferty, W. J., Mandin, J. Y., Massie, S. T., Mikhailenko, S. N., Miller, C. E., Moazzen-Ahmadi, N., Naumenko, O. V., Nikitin, A. V., Orphal, J., Perevalov, V. I., Perrin, A., Predoi-Cross, A., Rinsland, C. P., Rotger, M., Simecková, M., Smith, M. A. H., Sung, K., Tashkun, S. A., Tennyson, J., Toth, R. A., Vandaele, A. C., and Vander Auwera, J.: The HITRAN 2008 molecular spectroscopic database, J. Quant. Spectrosc. Radiat. Transfer, 110, 533-572, 2009.

Roy, D. P., Boschetti, L., Justice, C. O., and Ju, J.: The collection 5 MODIS burned area product - Global evaluation by comparison with the MODIS active fire product, Remote Sens. Environ., 112, 3690-3707, doi:16/j.rse.2008.05.013, 2008.

Seinfeld, J. H. and Pandis, S. N.: Atmospheric Chemistry and Physics - From Air Pollution to Climate Change, John Wiley \& Sons, New York, USA, 1998.

Sharkey, T. D., Wiberley, A. E., and Donohue, A. R.: Isoprene Emission from Plants: Why and How, Ann. Bot.-London, 101, 5-18, doi:10.1093/aob/mcm240, 2008.

Sharpe, S. W., Johnson, T. J., Sams, R. L., Chu, P. M., Rhoderick, G. C., and Johnson, P. A.: Gas-Phase Databases for Quantitative Infrared Spectroscopy, Appl. Spectrosc., 58, 1452-1461, 2004.

Simpson, I. J., Rowland, F. S., Meinardi, S., and Blake, D. R.: In- 
fluence of biomass burning during recent fluctuations in the slow growth of global tropospheric methane, Geophys. Res. Lett., 33, L22808, doi:10.1029/2006GL027330, 2006.

Singh, H. B., Kanakidou, M., Crutzen, P. J., and Jacob, D. J.: High concentrations and photochemical fate of oxygenated hydrocarbons in the global troposphere, Nature, 378, 50-54, doi:10.1038/378050a0, 1995.

Sun, Y. L., Zhang, Q., Anastasio, C., and Sun, J.: Insights into secondary organic aerosol formed via aqueous-phase reactions of phenolic compounds based on high resolution mass spectrometry, Atmos. Chem. Phys., 10, 4809-4822, doi:10.5194/acp-104809-2010, 2010.

Susott, R. A., Olbu, G. J., Baker, S. P., Ward, D. E., Kauffmann, J. B., and Shea, R. W.: Carbon, hydrogen, nitrogen, and thermogravimetric analysis of tropical ecosystem biomass, in Biomass Burning and Global Change, edited by: Levine, J. S., MIT Press, Cambridge, 249-259, 1996.

Trent, A., Davies, M. A., Fisher, R., Thistle, H., and Babbitt, R.: Evaluation of optical instruments for real-time, continuous monitoring of smoke particulates, Tech. Rep. 0025-2860-MTDC, USDA Forest Service, Missoula Technology and Development Center, Missoula, MT, USA, 2000.

Trentmann, J., Andreae, M. O., and Graf, H.-F.: Chemical processes in a young biomass-burning plume, J. Geophys. Res., 108, 4705, doi:10.1029/2003JD003732, 2003.

Trentmann, J., Yokelson, R. J., Hobbs, P. V., Winterrath, T., Christian, T. J., Andreae, M. O., and Mason, S. A.: An analysis of the chemical processes in the smoke plume from a savanna fire, J. Geophys. Res., 110, D12301, doi:10.1029/2004JD005628, 2005.

Urbanski, S. P., Salmon, J. M., Nordgren, B. L., and Hao, W. M.: A MODIS direct broadcast algorithm for mapping wildfire burned area in the western United States, Remote Sens. Environ., 113, 2511-2526, doi:10.1016/j.rse.2009.07.007, 2009a.

Urbanski, S. P., Hao, W. M., and Baker, S.: Chemical composition of wildland fire emissions, in Wildland Fires and Air Pollution, edited by: Bytnerowicz, A., Arbaugh, M., Riebau, A., and Andersen, C., 79-107, 2009b.

van der Werf, G. R., Randerson, J. T., Giglio, L., Collatz, G. J., Mu, M., Kasibhatla, P. S., Morton, D. C., DeFries, R. S., Jin, Y., and van Leeuwen, T. T.: Global fire emissions and the contribution of deforestation, savanna, forest, agricultural, and peat fires (19972009), Atmos. Chem. Phys., 10, 11707-11735, doi:10.5194/acp10-11707-2010, 2010.

Veres, P., Roberts, J. M., Burling, I. R., Warneke, C., de Gouw, J., and Yokelson, R. J.: Measurements of gas-phase inorganic and organic acids from biomass fires by negative-ion proton-transfer chemical-ionization mass spectrometry, J. Geophys. Res., 115, D23302, doi:10.1029/2010JD014033, 2010.

Wade, D. D. and Lunsford, J. D.: A guide for prescribed fire in southern forests, USDA Forest Service Southern Region, Atlanta, GA, USA, 56 pp., 1989.

Warneke, C., Roberts, J. M., Veres, P., Gilman, J., Kuster, W. C., Burling, I., Yokelson, R., and de Gouw, J. A.: VOC identification and inter-comparison from laboratory biomass burning using PTR-MS and PIT-MS, Int. J. Mass Spectrom., 303, 6-14, doi:10.1016/j.ijms.2010.12.002, 2011.
Webster, C. R., May, R. D., Trimble, C. A., Chave, R. G., and Kendall, J.: Aircraft (ER-2) laser infrared absorption spectrometer (ALIAS) for in-situ stratospheric measurements of HCI, $\mathrm{N}_{2} \mathrm{O}, \mathrm{CH}_{4}, \mathrm{NO}_{2}$, and $\mathrm{HNO}_{3}$, Appl. Opt., 33, 454-472, doi:10.1364/AO.33.000454, 1994.

Yokelson, R. J., Burling, I. R., Urbanski, S. P., Atlas, E. L., Adachi, K., Buseck, P. R., Wiedinmyer, C., Akagi, S. K., Toohey, D. W., and Wold, C. E.: Trace gas and particle emissions from open biomass burning in Mexico, Atmos. Chem. Phys., 11, 67876808, doi:10.5194/acp-11-6787-2011, 2011.

Yokelson, R. J., Christian, T. J., Bertschi, I. T., and Hao, W. M.: Evaluation of adsorption effects on measurements of ammonia, acetic acid, and methanol, J. Geophys. Res., 108, 4649, doi:10.1029/2003JD003549, 2003.

Yokelson, R. J., Christian, T. J., Karl, T. G., and Guenther, A.: The tropical forest and fire emissions experiment: laboratory fire measurements and synthesis of campaign data, Atmos. Chem. Phys., 8, 3509-3527, doi:10.5194/acp-8-3509-2008, 2008.

Yokelson, R. J., Crounse, J. D., DeCarlo, P. F., Karl, T., Urbanski, S., Atlas, E., Campos, T., Shinozuka, Y., Kapustin, V., Clarke, A. D., Weinheimer, A., Knapp, D. J., Montzka, D. D., Holloway, J., Weibring, P., Flocke, F., Zheng, W., Toohey, D., Wennberg, P. O., Wiedinmyer, C., Mauldin, L., Fried, A., Richter, D., Walega, J., Jimenez, J. L., Adachi, K., Buseck, P. R., Hall, S. R., and Shetter, R.: Emissions from biomass burning in the Yucatan, Atmos. Chem. Phys., 9, 5785-5812, doi:10.5194/acp-9-5785-2009, 2009.

Yokelson, R. J., Goode, J. G., Ward, D. E., Susott, R. A., Babbitt, R. E., Wade, D. D., Bertschi, I., Griffith, D. W. T., and Hao, W. M.: Emissions of formaldehyde, acetic acid, methanol, and other trace gases from biomass fires in North Carolina measured by airborne Fourier transform infrared spectroscopy, J. Geophys Res., 104, 30109-30125, doi:10.1029/1999JD900817, 1999.

Yokelson, R. J., Karl, T., Artaxo, P., Blake, D. R., Christian, T. J., Griffith, D. W. T., Guenther, A., and Hao, W. M.: The Tropical Forest and Fire Emissions Experiment: overview and airborne fire emission factor measurements, Atmos. Chem. Phys., 7, 5175-5196, doi:10.5194/acp-7-5175-2007, 2007a.

Yokelson, R. J., Urbanski, S. P., Atlas, E. L., Toohey, D. W., A1varado, E. C., Crounse, J. D., Wennberg, P. O., Fisher, M. E., Wold, C. E., Campos, T. L., Adachi, K., Buseck, P. R., and Hao, W. M.: Emissions from forest fires near Mexico City, Atmos. Chem. Phys., 7, 5569-5584, doi:10.5194/acp-7-5569-2007, 2007b.

Yokelson, R. J., Griffith, D. W. T., and Ward, D. E.: Openpath Fourier transform infrared studies of large-scale laboratory biomass fires, J. Geophys. Res., 101, 21067-21080, doi:10.1029/96JD01800, 1996.

Yokelson, R. J., Susott, R., Ward, D. E., Reardon, J., and Griffith, D. W. T.: Emissions from smoldering combustion of biomass measured by open-path Fourier transform infrared spectroscopy, J. Geophys. Res., 102, 18865-18877, doi:10.1029/97JD00852, 1997. 